\title{
Article
}

\section{The Comparative Economics of ICT, Environmental Degradation and Inclusive Human Development in Sub-Saharan Africa}

\author{
Asongu, Simplice A, Nwachukwu, Jacinta C. and Pyke, Chris \\ Available at http://clok.uclan.ac.uk/24482/ \\ Asongu, Simplice A, Nwachukwu, Jacinta C. ORCID: 0000-0003-2987-9242 and \\ Pyke, Chris ORCID: 0000-0001-6576-2709 (2019) The Comparative Economics \\ of ICT, Environmental Degradation and Inclusive Human Development in Sub- \\ Saharan Africa. Social Indicators Research, 143 (3). pp. 1271-1297. ISSN \\ 0303-8300
}

It is advisable to refer to the publisher's version if you intend to cite from the work. http://dx.doi.org/10.1007/s11205-018-2009-x

For more information about UCLan's research in this area go to http://www.uclan.ac.uk/researchgroups/ and search for <name of research Group>.

For information about Research generally at UCLan please go to http://www.uclan.ac.uk/research/

All outputs in CLoK are protected by Intellectual Property Rights law, including Copyright law. Copyright, IPR and Moral Rights for the works on this site are retained by the individual authors and/or other copyright owners. Terms and conditions for use of this material are defined in the policies page. 


\title{
The Comparative Economics of ICT, Environmental Degradation and Inclusive Human Development in Sub-Saharan Africa
}

\author{
Forthcoming: Social Indicators Research \\ Simplice A. Asongu \\ Development Finance Centre \\ Graduate School of Business, \\ University of Cape Town, Cape Town, South Africa. \\ $\&$ \\ Department of Economics \& Development Studies, \\ Covenant University, Ota, Ogun State, Nigeria \\ E-mails: asongusimplice@yahoo.com / \\ asongus@afridev.org
}

\section{Jacinta C. Nwachukwu}

Lancashire School of Business and Enterprise

University of Central Lancashire

Preston, PR2 2HE

United Kingdom

Email: j.ch.nwachukwu@gmail.com

\section{Chris Pyke}

Lancashire School of Business and Enterprise

University of Central Lancashire

Preston, PR2 2HE

United Kingdom

Email: cpyke2@uclan.ac.uk

\begin{abstract}
This study examines how information and communication technology (ICT) could be employed to dampen the potentially damaging effects of environmental degradation in order to promote inclusive human development in a panel of 44 Sub-Saharan African countries. ICT is captured with internet and mobile phone penetration rates whereas environmental degradation is measured in terms of $\mathrm{CO}_{2}$ emissions per capita and $\mathrm{CO}_{2}$ intensity. The empirical evidence is based on Fixed Effects and Tobit regressions using data from 2000-2012. In order to increase the policy relevance of this study, the dataset is decomposed into fundamental characteristics of inclusive development and environmental degradation based on income levels (Low income versus (vs.) Middle income); legal origins (English Common law vs. French Civil law); religious domination (Christianity vs. Islam); openness to sea (Landlocked vs. Coastal); resource-wealth (Oil-rich vs. Oil-poor) and political stability (Stable vs. Unstable).
\end{abstract}


Baseline findings broadly show that improvement in both of measures of ICT would significantly diminish the possibly harmful effect of $\mathrm{CO}_{2}$ emissions on inclusive human development. When the analysis is extended with the abovementioned fundamental characteristics, we observe that the moderating influence of both our ICT variables on $\mathrm{CO}_{2}$ emissions is higher in the group of English Common law, Middle income and Oil-wealthy countries than in the French Civil law, Low income countries and Oil-poor countries respectively. Theoretical and practical policy implications are discussed.

JEL Classification: C52; O38; O40; O55; P37

Keywords: CO2 emissions; ICT; Economic development; Africa

\section{Acknowledgement}

The authors are indebted to the editor and reviewers for constructive comments.

\section{Introduction}

The comparative economics of information and communication technology (ICT), environmental degradation and inclusive human development in Sub-Saharan Africa (SSA) can be explored along four main motivational strands. They are: (i) the burgeoning trend of ICT; (ii) the growing policy syndrome of exclusive human development ${ }^{1}$; (iii) challenging environmental degradation in the light of post-2015 Sustainable Development Goals (SDGs) and (iv) shortcomings in the extant literature. These underpinning aspects of the literature are expanded in subsequent paragraphs in chronological order.

First, arguments in Penard et al. (2012) and Tchamyou (2017) in recent ICT literature are consistent with the perception that there are greater opportunities for ICT penetration in SSA than in the other world regions. These regions, in particular Europe, Asia and North America largely consist of high income economies. Such indicates that the potential benefits of ICT penetration can be leveraged by policymakers in underdeveloped economies like SSA to stimulate environmental sustainability and inclusive human development.

Second, exclusive human development represents a sobering policy syndrome in SSA. Indeed, a World Bank report on attainment of the Millennium Development Goal (MDG) in 2015 revealed that extreme poverty has been decreasing in all parts of the world with the

\footnotetext{
${ }^{1}$ Fosu (2013a) defines policy syndromes as situations that are detrimental to growth: 'administered redistribution', 'state breakdown', 'state controls', and 'suboptimal inter temporal resource allocation'. Within the framework of this study, policy syndromes are considered as issues that merit strategic action in order to achieve sustainable and inclusive human development.
} 
exception of the Sub-Saharan Africa region. This observation was supported by a subsequent study by Asongu and Le Roux (2017) in which the number of people living in extreme poverty in SSA was shown to have been growing since the 1990s. This evidence substantially contrasts with the assessment by Fosu (2015) and Asongu and Nwachukwu, (2016) of a growth resurgence in the SSA sub-region which began in the mid-1990s. Comparing and contrasting the narrative in the various academic papers evidently reveals that the fruits of economic prosperity from the more than twenty years of growth revival have not been fairly distributed amongst the population in SSA. Furthermore, it is rational to presume that the corresponding growth recovery has been associated with more 'green house gas' emissions which are normally linked to economic activity and prosperity. Such green house gas emissions have been documented to have a disproportionate impact on the poor and hence represent a considerable challenge to initiatives to eradicate extreme poverty in the post-2015 sustainable development era (Akinyemi et al., 2015).

Third, whereas environmental sustainability is a major policy concern in the post-2015 development agenda, the worry is particularly palpable for the SSA sub-region for at least four main reasons. (i) It is logical to infer that the more than two decades of growth resurgence in SSA has been accompanied by relatively more $\mathrm{CO}_{2}$ emissions. Indeed, Asongu and Gupta (2016) noted that the sub-region is home for seven of the ten fastest growing world economies. (ii) In accordance with Akinyemi et al. (2015), one of the most challenging policy syndromes in the post-2015 sustainable development era is energy crisis. Shurig (2015) articulates that this crisis is most apparent in SSA because only 5 percent of the population in the sub-region has access to energy. The narrative further maintains that the consumption of energy in SSA which is about 17 percent of the global average is equivalent to the total energy consumed by the state of New York in the United States of America (USA). (iii) The economic implications of the poor management of the energy crisis in most African countries were explored in Anyangwe (2014). A glaring example of such mismanagement is the case of Nigeria where chronic energy shortage is compensated with government subsidies on petroleum imports. These subsidized fuel imports are then used in household electricity generators to avoid/reduce the negative externalities of electricity outage/shortage (Apkan, 2012). A more rational approach would have been to raise the public investment in renewable sources of energy with the view of reducing greenhouse emissions. (iv) Climate change which is one of the most critical policy syndromes in the post-2015 sustainable development era is a direct consequence of fossil fuel consumption (see Huxster et al., 2015). Furthermore, according to Kifle (2008), African 
countries will be most negatively affected by the consequences of global warming. Our interest in $\mathrm{CO}_{2}$ emissions builds on the evidence that it represents about 75 percent of such global greenhouse gas emissions (see Akpan, 2012).

The present study is positioned as a reconciliation of the aforementioned three strands of literature. The aim is to unite the disparate parts of the literature by investigating how ICT penetration (explored in the first strand) can be used as a policy instrument to mitigate the potentially adverse consequences of $\mathrm{CO}_{2}$ emissions (discussed in the third part of the literature) in order to boost inclusive and sustainable human development (covered in the second strand). The concepts of inclusive human development articulated in this paper are theoretically linked to the Sustainable Development Goals (SDGs) pronounced by the United Nations in 2015 in two important ways. First, in order for inclusive human development to be sustainable, it needs to be persistent and secondly, for sustained development to be long-lasting, it should be inclusive (see Amavilah et al., 2017). Such provides the justification for our decision to connect ICT, $\mathrm{CO}_{2}$ emissions and inclusive human development.

We propose that improvement in ICT mechanisms and their penetration can significantly dampen $\mathrm{CO}_{2}$ emissions by, among others: (i) decreasing unnecessary transportation costs and (ii) increasing management efficiency in the running of businesses and household budgets. More specifically, we argue that transportation costs that are saved with the help of a quick dial of a mobile phone (or use of an internet connection) can substantially curb $\mathrm{CO}_{2}$ emissions that would have been associated with transport costs which otherwise would have been incurred by parties concerned, to physically displace themselves in a quest to garner relevant information. Hence, with improvement in the collection and sharing of information, ICT penetration decreases informational rents linked to $\mathrm{CO}_{2}$ emissions. It is expected that the cost savings there from would be invested in other facilitators of inclusive human development such as: health care, education, housing, and sanitation. These items are directly related to the three main components of the inequality adjusted human development index (IHDI), employed as the outcome variable in this study.

In the light of the above argument, the intuition for the present inquiry falls within the framework of theoretical exploration as it highlights both conceptual and practical consequences of the subject of research. Therefore, we join a stream of literature in arguing that applied econometrics should not be exclusively limited to either the rejection or the acceptance of existing theories (Costantini \& Lupi, 2005; Narayan et al., 2011). Therefore, an empirical exercise which is motivated by commonsense may set the groundwork for theory-building in 
future studies. In order to increase the policy relevance of this paper, the dataset is decomposed into fundamental characteristics of inclusive human development and environmental degradation based on income levels (low income versus (vs.) middle income); legal origins (English Common law vs. French Civil law); religious domination (Christianity vs. Islam); openness to sea (landlocked vs. Coastal); resource-wealth (oil-rich vs. oil-poor) and political stability (stable vs. unstable). The reasons motivating the choice of these core features are substantiated in Section 2.

This study steers clear of recent ICT literature which has focused primarily on, among others: (i) living standards (Chavula, 2013); economic development (Qureshi, 2013a; Levendis \& Lee, 2013); welfare externalities (Carmody, 2013; Qureshi, 2013b, 2013c); Africa's information revolution from the perspectives of production networks and technical regimes (Murphy \& Carmody, 2015); progress in the banking sector (Kamel, 2005); life for all (Ponelis \& Holmner, 2013a, 2013b; Kivuneki et al., 2011) and sustainable development (Byrne, 2011) in developing nations. Thus, while the human and socioeconomic benefits of ICT have been substantially covered in recent literature, we still know very little about the interconnections between ICT, inclusive human development and environmental degradation ${ }^{2}$.

The positioning of this paper also steers clear of $\mathrm{CO}_{2}$ emissions literature which is dominated by two strands. The first borders on the relationship between environmental pollution and economic growth with particular emphasis on the Environmental Kuznets Curve (EKC) hypothesis (see Akbostanci et al., 2009; Diao et al., 2009; He \& Richard, 2010) ${ }^{3}$. The second aspect focuses on two main tendencies, notably: (i) the relationship between economic growth, energy consumption and environmental pollution (Jumbe, 2004; Ang, 2007; Odhiambo, 2009a, 2009b; Apergis \& Payne, 2009; Ozturk \& Acaravci, 2010; Menyah \& Wolde-Rufael, 2010; Begum et al., 2015; Bölük \& Mehmet, 2015) and (ii) connections between energy consumption and economic growth (Mehrara, 2007; Esso, 2010).

A major drawback to the current literature is a collective absence of a policy variable with which $\mathrm{CO}_{2}$ emissions can be mitigated so as to enhance sustainable development. We argue that studies that are set exclusively on the linkages between macroeconomic variables (energy consumption and economic growth) and $\mathrm{CO}_{2}$ emissions have limited practical

\footnotetext{
${ }^{2}$ There is also an evolving stream of African development literature on the relevance of mobile technologies on inclusive development outcomes that has not focused on the environment (Afutu-Kotey et al., 2017; Asongu \& Boateng, 2018; Bongomin et al., 2018; Gosavi, 2018; Hubani \& Wiese, 2018; Isszhaku et al., 2018; Minkoua Nzie et al., 2018; Muthinja \& Chipeta, 2018; Abor et al., 2018).

${ }^{3}$ According to the EKC hypothesis, in the long term, there is an inverted U-shaped relationship between per capita income and environmental degradation.
} 
relevance because policy makers are not informed of corresponding instruments by which $\mathrm{CO}_{2}$ emissions can be reduced in order to boost economic and human development outcomes. Therefore, this study addresses these aforementioned shortcomings by introducing ICT as the policy variable through which the emission of $\mathrm{CO}_{2}$ can be mitigated so as to stimulate inclusive human development. To illustrate this process, this study calculates the effect of ICT penetration using estimates of both the unconditional effect $\mathrm{CO}_{2}$ emissions and the conditional impact of the interaction between ICT and $\mathrm{CO}_{2}$ emissions. The use of such interactive regressions to investigate the net effect of a policy instrument is in accordance with the extant contemporary literature on the use of ICT to modulate the potentially negative impact of globalisation on economic development outcomes (Asongu, 2018).

The rest of the study is structured as follows. The conceptual framework for comparative economic development is discussed in Section 2. Section 3 describes the data and empirical methodology. The empirical results are presented in Section 4 whereas Section 5 concludes with policy recommendations and future research directions.

\section{Intuition for comparative economic development}

This section discusses the foundations for comparative economic development in inclusive human development and environmental degradation. The aim is to provide the basis for disaggregating the study sample into fundamental characteristics based on political stability, natural resources, openness to sea, religious domination, legal origins and income levels. It is important to note that the policy relevance of these core features have been documented in recent comparative development literature (see Narayan et al., 2011; Mlachila et al., 2017; Asongu \& Le Roux, 2017). Hence, in the narratives that follow, we articulate the manner in which inclusive development and environmental degradation are associated with the selected fundamental features.

First, income level is logically a positive function of the ability of governments to invest in schemes which help to address challenges to environmental degradation. Therefore, it follows that higher income countries are more likely to have the financial infrastructure needed to deal with issues relating to climate change and environmental pollution. Furthermore, compared to poor countries, wealthier nations have been documented to have good governance and institutions that promote inclusive development. The association between institutional arrangements and development externalities (human and environmental) is explored in the papers by Fosu, (2013a, 2013b), Anyanwu and Erhijakpor, (2014) and Efobi, (2015). 
Second, the basis of legal origins has been substantially documented in the literature both general (La Porta et al., 1998, 1999) and African-specific (Agbor, 2015) terms. According to the narrative, French Civil law countries are associated with less effective institutions, compared to their English Common law counterparts because of their relatively less flexible political systems (Beck et al., 2003). Therefore, in the light of the flexibility argument, English Common law countries are more likely to adapt more quickly to vagaries in environmental conditions, relative to French Civil law countries. In a nutshell, the institutional web of formal rules, informal norms and characteristics of law enforcement arrangements underpinning the legal traditions affect the ability of governments to, inter alia: (i) formulate and implement policies that provide public goods and enhance inclusive development and (ii) address issues relating to environmental degradation measures such as $\mathrm{CO}_{2}$ emissions.

Third, the basis for the wealth of nations in terms of income levels identified in the first part of the literature above extends to natural resources-rich countries. The premise for this extension is the supposition of a strong association between the levels of income and natural resource in a country. It is worthwhile to qualify this pronunciation with the caution that natural resource-wealth could also be associated with high levels of environmental mismanagement and poor institutions. A good example is Nigeria, Africa's largest oil exporting nation and the most populous. It adopted a fossil-fuel subsidy scheme as a means of addressing concerns relating to the chronic outages of and shortages in electricity. Furthermore, some explanations in the literature maintain that nations which have acknowledged natural resource scarcity have also been the most equipped at implementing policies that promote sustained and inclusive development (Amavilah, 2016; Fosu, 2013b; America, 2013). A good example of a resource-poor country that has devoted comparatively more efforts towards the improvement of environmental and inclusive human development outcomes is Rwanda. It banned the use of plastic bags and substantially promoted gender equality within its public institutions (see Sharp et al., 2010; Debusscher \& Ansoms, 2013).

Fourth, Arvis et al (2007) remarked that landlocked countries incur more institutional and economic costs relative to their coastal counterparts. This viewpoint is motivated by the higher propensity of landlocked countries to depend on road traffic as transportation means with the concomitant increase in $\mathrm{CO}_{2}$ emissions. Therefore, it is logical to infer that the sustainable human development in landlocked countries depends largely on the effectiveness of their governments and public institutions in designing and implementing policies including the use of ICT to dampen the damaging effect of environmental pollution. 
Fifth, the basis for religious domination can be understood from the fact that religious solidarity is conducive for sustainable human welfare. Moreover, given that Islam-dominated countries are more conservative than their Christian-oriented counterparts, it is reasonable to suppose that the latter have comparatively better institutions which are indispensible for sound environmental and inclusive human development outcomes. Hence, the institutions surrounding liberal (versus conservative) religious cultures affect cross-country difference in sustainable development (Roudometof, 2014).

Sixth, politically-stable nations are more likely to engineer conditions which enable sound environmental management and inclusive human development. The insight is supported by Beegle et al. (2016) who showed that politically fragile countries have experienced comparatively poor economic development outcomes.

\section{Data and Methodology}

\subsection{Data}

This study examines a panel of forty-four countries in SSA with data from World Development Indicators and the United Nations Development Program (UNDP) for the period 2000-2012 ${ }^{4}$. Whereas the choice of the periodicity is contingent on data availability constraints, the motivation for the scope of SSA has been justified in the introductory section. Inclusive human development is measured with the inequality adjusted human development index (IHDI), in conformity with the latest inclusive development literature (Asongu et al., 2015). The human development index (HDI) represents a national average of results in three principal areas, notably: health and long life, knowledge and basic income. The IHDI goes a step further by adjusting the HDI to include prevailing levels of inequality in the underlying three dimensions. In other words, the IHDI also takes into consideration the manner in which the three primary components of human welfare are distributed within the general population.

In accordance with the literature, ICT is measured with rates of penetration of mobile phone (per 100 people) and the internet (per 100 people) (Penard et al., 2012; Tchamyou, 2017; Tchamyou et al., 2018; Amavilah et al., 2017). Two indicators are used to capture the extent of environmental degradation. They are: $\mathrm{CO}_{2}$ emissions per capita and $\mathrm{CO}_{2}$ intensity. To account for variable omission bias, four control variables are considered, namely: education

\footnotetext{
${ }^{4}$ The 44 countries are: Angola, Benin, Botswana, Burkina Faso, Burundi, Cameroon, Cape Verde, Central African Republic, Chad, Comoros, Congo Democratic. Republic., Congo Republic, Cote d'Ivoire, Djibouti, Ethiopia, Gabon, Gambia, Ghana, Guinea, Guinea-Bissau, Kenya, Lesotho, Liberia, Madagascar, Malawi, Mali, Mauritania, Mauritius, Mozambique, Namibia, Niger, Nigeria, Rwanda, Sao Tome \& Principe, Senegal, Seychelles, Sierra Leone, South Africa, Sudan, Swaziland, Tanzania, Togo, Uganda and Zambia.
} 
quality, private domestic credit, foreign aid and foreign direct investment. We expect foreign aid to have a negative effect on inclusive human development (see Asongu, 2014), whereas the influence of the other control variables should be the opposite. Foreign direct investment and private domestic credit have been confirmed by a broad stream of literature to positively affect inclusive human development because they provide enabling conditions which facilitate social mobility and reduction of unemployment (Mishra et al., 2011; Anand et al., 2012; Seneviratne $\&$ Sun, 2013; Mlachila et al., 2017). Although education has been proven to promote inclusive development (see Dunlap-Hinkler et al., 2010), primary school education has been specifically recognised to generate higher positive social returns when countries are at initial levels of industrialisation (see Asiedu, 2014; Petrakis \& Stamakis, 2002; Tchamyou, 2018a). Consequently, in the light of the construction of the pupil-teacher ratio used in the present study, we expect a negative sign on the primary education variable. This is essentially because an increasing ratio denotes decreasing quality in primary education as higher student enrolment is not compensated by a similar rise in the number qualified teaching staff.

Given the above information, the selection of the control variables has been motivated by intuition, constituents of the IHDI and the existing literature on inclusive development. For example, while education is a component of IHDI, the selection of the other variables is supported by discussion in the literature. More details on the definitions of variables and sources can be found in Appendix 1. Appendix 2 provides the summary statistics. The correlation matrix is presented in Appendix 3.

We now discuss the criteria for the choice of fundamental features discussed in Section $2^{5}$, which are broadly in accord with the literature on comparative development (see (Narayan et al., 2011; Mlachila et al., 2017; Asongu \& Le Roux, 2017). Categorization of nations according to legal origins is from La Porta et al. (2008, p. 289) while the decomposition of countries by income groups is consistent with the World Bank's classification ${ }^{6}$. Stratification by natural resource-wealth is exclusively based on petroleum exports which represent at least 30 percent of the country's GDP for a minimum of one decade of the study period. The Central Intelligence Agency (CIA) World Fact Book (CIA, 2011) provides information on religiousdomination, whereas landlocked countries are directly observable from an African map.

\footnotetext{
${ }^{5}$ Whereas we have provided motivations for the choice of fundamental characteristics in Section 2, in this section, we discuss the information criteria used in the selection of underlying fundamental characteristics.

${ }^{6}$ There are four main World Bank income groups: (i) high income, $\$ 12,276$ or more; (ii) upper middle income, $\$ 3,976-\$ 12,275$; (iii) lower middle income, $\$ 1,006-\$ 3,975$ and (iv) low income, $\$ 1,005$ or less.
} 
Politically-unstable countries are those that have experienced political instability and/or violence for at least half of the period being investigated. Appendix 4 provides the categorisation of countries.

\subsection{Methodology}

Two empirical strategies are adopted to control for specific characteristics, notably: (i) Fixed Effects (FE) regressions are used to control for the unobserved heterogeneity and (ii) Tobit regressions corrects for limitations in the range in the dependent variable dataset. On the first estimation approach, when a panel entails observations on fixed and comparatively small sets of cross section units (such as the specific fundamental characteristics outlined earlier), there is a presumption in favour of FE. This justification has been used in recent inclusive human development literature employing the same outcome variable (see Asongu \& Nwachukwu, 2018). Concerning the use of Tobit model, the suitability of this approach to deal with errors arising from a limited range of the dependent variable dataset were confirmed in the study by Asongu and le Roux (2017) which employs the same inclusive human development outcome variable.

The panel FE model is presented as follows:

$$
I H D_{i, t}=\partial_{0}+\partial_{1} C O_{i, t-1}+\partial_{2} I C_{i, t-1}+\partial_{3} C O I C_{i, t-1}+\sum_{h=1}^{4} \omega_{h} W_{h, i, t-\tau}+\eta_{i}+\varepsilon_{i, t},
$$

where, $I H D_{i, t}$ is inclusive human development for country $i$ at period $t ; \partial_{0}$ is a constant; $C O_{i, t-1}$ is a $\mathrm{CO}_{2}$ emissions variable for country $i$ at period $t-1 ; I C_{i, t-1}$ represents an ICT (mobile phone penetration or internet penetration) variable for country $i$ at an initial period $t-1 ; \mathrm{COIC}_{i, t-1}$, is an interaction term representing the multiplication between a $\mathrm{CO}_{2}$ emissions variable and an ICT variable for country $i$ at the previous period $t-1$; $W$ is the vector of control variables (education quality, private domestic credit, foreign aid and foreign direct investment); $h$ is the number of control variables; $\eta_{i}$ is the country-specific effect and $\varepsilon_{i, t}$ the error term. The purpose of lagging the independent variables of interest by one period is to correct the potential endogeneity bias (see Asongu et al., 2017).

Since we are dealing with an empirical modelling that involves the employment of interactive regressions, it is imperative that we briefly highlight some pitfalls that could be associated with such specifications. In accordance with Brambor et al. (2006), all constitutive 
variables are included in all the regression models. Furthermore, in order for the estimated parameters to make economic sense, they should be interpreted as conditional or marginal effects.

Given that the IHDI theoretically falls between 0 and 1, it is not appropriate to employ the Ordinary Least Squares (OLS) estimation technique. Consistent with empirical literature, a double-censored Tobit estimation approach is used to control for the limited range in the dataset for the dependent indicator (Kumbhakar \& Lovell, 2000; Koetter et al., 2008; McDonald, 2009; Coccorese \& Pellecchia, 2010; Ariss, 2010; Ajide et al., 2018). This is in line with the composition of the IHDI because it has minimum and maximum values of 0.129 and 0.768 respectively.

The standard Tobit model (Tobin, 1958; Carsun \& Sun, 2007) is as follows:

$$
y_{i, t}^{*}=\alpha_{0}+\beta X_{i, t}+\varepsilon_{i, t}
$$

where $y_{i, t}^{*}$ is a latent response variable, $X_{i, t}$ is an observed $1 \times k$ vector of explanatory variables and $\varepsilon_{i, t} \approx$ i.i.d. $\mathrm{N}\left(0, \sigma^{2}\right)$ and is independent variable of $X_{i, t}$. Instead of observing $y_{i, t}^{*}$, we observe $y_{i, t}$ :

$$
y_{i, t}=\left\{\begin{array}{c}
y_{i, t}^{*} \text { if } y_{i, t}^{*}>\gamma \\
0, \text { if } y_{i, t}^{*} \leq \gamma,
\end{array}\right.
$$

where $\gamma$ is a non stochastic constant. In other words, the value of $y_{i, t}^{*}$ is missing when it is less than or equal to $\gamma$.

\section{Empirical Results}

This section presents the empirical results. Table 1 presents baseline results. Tables 2 and Table 3 respectively report extensions models corresponding to Fixed Effects and Tobit regressions when the data is disaggregated into fundamental characteristics. Table 1 includes two specifications corresponding to Fixed Effects regressions and two specifications relating to Tobit regressions. For either estimation approach, four main regressions are considered: the first-two correlates each of the ICT variables to $\mathrm{CO}_{2}$ emissions per capita and the last-two regressions connect the ICT variables with $\mathrm{CO}_{2}$ intensity. In order to assess the relevance of ICT in moderating $\mathrm{CO}_{2}$ emissions for inclusive human development, ICT (mobile phone and internet penetration rates) are interacted with each of our selected indicators of $\mathrm{CO}_{2}$ emissions. 
The net effect on inclusive human development is subsequently computed from both the estimated conditional and unconditional effects. Consequently, the role of ICT in tempering the damaging impact of $\mathrm{CO}_{2}$ emissions on inclusive human development is examined from two viewpoints, namely: marginal and net effects.

Whereas the marginal effects are the estimated coefficients corresponding to the interaction between $\mathrm{CO}_{2}$ emission variables and ICT indicators, net impacts are also computed to examine the overall impact of ICT in $\mathrm{CO}_{2}$ emissions for inclusive human development. For example, in the second column of Table 1 , the net effect of mobile phone penetration on $\mathrm{CO}_{2}$ emission per capita for inclusive human development is $0.0115([-0.0001 \times 24.428]+[0.014])$. In the computation, the mean value of mobile phone penetration is 24.428 ; the unconditional effect of $\mathrm{CO}_{2}$ emissions per capita is 0.014 while the conditional effect from the interaction between $\mathrm{CO}_{2}$ emissions per capita and mobile phone penetration is -0.0001 .

The following relationships can be established from Table 1. First, ICT interacts with $\mathrm{CO}_{2}$ emissions to increase inclusive human development and where the influences are comparable (see $6^{\text {th }}$ and $7^{\text {th }}$ columns), the net effect from mobile phone penetration is slightly higher than the corresponding net effect from internet penetration. Second, the significant control variables have the expected signs. 
Table 1: Baseline Fixed Effects and Tobit Regressions

\begin{tabular}{|c|c|c|c|c|c|c|c|c|}
\hline & & Depen & ent variable: & nequality A & justed Huma & Developme & (IHDI) & \\
\hline & & Fixed Effec & Regressions & & & Tobit R & ressions & \\
\hline & $\begin{array}{r}\mathrm{CO} 2 \text { emiss } \\
(\mathrm{CO}\end{array}$ & $\begin{array}{l}\text { ns per capita } \\
\text { mtpc) }\end{array}$ & $\begin{array}{r}\mathrm{CO}_{2} \\
(\mathrm{CO}\end{array}$ & $\begin{array}{l}\text { tensity } \\
\text { nten) }\end{array}$ & $\mathrm{CO} 2$ emissi & $\begin{array}{l}\text { ns per capita } \\
\text { ntpc) }\end{array}$ & $\begin{array}{r}\mathrm{CO}_{2} \\
(\mathrm{CO}\end{array}$ & $\begin{array}{l}\text { tensity } \\
\text { nten) }\end{array}$ \\
\hline & Mobile & Internet & Mobile & Internet & Mobile & Internet & Mobile & Internet \\
\hline Constant & $\begin{array}{l}0.425 * * * \\
(0.000)\end{array}$ & $\begin{array}{l}0.440 * * * \\
(0.000)\end{array}$ & $\begin{array}{l}\text { 0.458**** } \\
(0.000)\end{array}$ & $\begin{array}{l}0.458 * * * \\
(0.000)\end{array}$ & $\begin{array}{l}0.464 * * * \\
(0.000)\end{array}$ & $\begin{array}{l}0.473 * * * \\
(0.000)\end{array}$ & $\begin{array}{l}0.504 * * * \\
(0.000)\end{array}$ & $\begin{array}{l}0.485 * * * \\
(0.000)\end{array}$ \\
\hline Mobile (Mob)(-1) & $\begin{array}{l}\mathbf{0 . 0 0 0 8} * * * \\
(\mathbf{0 . 0 0 0 )}\end{array}$ & --- & $\begin{array}{l}\mathbf{0 . 0 0 0 8} * * * \\
(\mathbf{0 . 0 0 0 )}\end{array}$ & --- & $\begin{array}{l}\mathbf{0 . 0 0 1} * * * \\
(\mathbf{0 . 0 0 0 )}\end{array}$ & --- & $\begin{array}{l}\mathbf{0 . 0 0 1 * * *} \\
(\mathbf{0 . 0 0 0 )}\end{array}$ & --- \\
\hline Internet (Inter)(-1) & --- & $\begin{array}{l}0.004 * * * \\
(0.000)\end{array}$ & --- & $\begin{array}{l}0.005 * * * \\
(\mathbf{0 . 0 0 0 )}\end{array}$ & --- & $\begin{array}{l}\mathbf{0 . 0 1 0} * * * \\
(\mathbf{0 . 0 0 0 )}\end{array}$ & --- & $\begin{array}{l}0.005 * * * \\
(0.004)\end{array}$ \\
\hline $\mathrm{CO} 2 \mathrm{mtpc}(-1)$ & $\begin{array}{l}\text { 0.014* } \\
(0.083)\end{array}$ & $\begin{array}{l}0.002 \\
(0.840)\end{array}$ & --- & --- & $\begin{array}{l}\mathbf{0 . 0 5 2} * * * \\
(\mathbf{0 . 0 0 0 )}\end{array}$ & $\begin{array}{l}0.037 * * * \\
(0.000)\end{array}$ & --- & --- \\
\hline CO2inten(-1) & --- & -- & $\begin{array}{l}0.002 \\
(0.202)\end{array}$ & $\begin{array}{l}0.005 * * * \\
(0.000)\end{array}$ & --- & --- & $\begin{array}{l}-0.002 \\
(0.312)\end{array}$ & $\begin{array}{l}-0.003 \\
(0.129)\end{array}$ \\
\hline $\mathrm{CO} 2 \mathrm{mtpc} \times \operatorname{Mob}(-1)$ & $\begin{array}{l}- \\
0.0001 * * * * \\
(0.001)\end{array}$ & --- & --- & --- & $\begin{array}{l}-0.0003 * * * \\
(0.000)\end{array}$ & --- & --- & --- \\
\hline $\mathrm{CO} 2 \mathrm{mtpc} \times$ Inter(-1) & -- & $\begin{array}{l}-\mathbf{0 . 0 0 1} * * * \\
(\mathbf{0 . 0 0 0 )}\end{array}$ & --- & --- & --- & $\begin{array}{l}-0.001 * * * \\
(0.000)\end{array}$ & --- & --- \\
\hline CO2inten $\times$ Mob(-1) & --- & -- & $\begin{array}{l}-0.00006 \\
(0.182)\end{array}$ & --- & --- & --- & $\begin{array}{l}0.0001 \\
(0.318)\end{array}$ & --- \\
\hline CO2inten $\times$ Inter(-1) & --- & --- & --- & $\begin{array}{l}\mathbf{0 . 0 0 5 * * *} \\
(\mathbf{0 . 0 0 0 )}\end{array}$ & --- & --- & --- & $\begin{array}{l}0.001 \\
(0.138)\end{array}$ \\
\hline Education(-1) & $\begin{array}{l}0.00007 \\
(0.773)\end{array}$ & $\begin{array}{l}-0.0003 \\
(0.137)\end{array}$ & $\begin{array}{l}0.0002 \\
(0.514)\end{array}$ & $\begin{array}{l}-0.0001 \\
(0.630)\end{array}$ & $\begin{array}{l}-0.001 * * * \\
(0.000)\end{array}$ & $\begin{array}{l}-\mathbf{0 . 0 0 1} * * * \\
(0.000)\end{array}$ & $\begin{array}{l}-0.001 * * \\
(0.021)\end{array}$ & $\begin{array}{l}-0.0004 \\
(0.359)\end{array}$ \\
\hline Credit(-1) & $\begin{array}{l}-0.00001 \\
(0.959)\end{array}$ & $\begin{array}{l}\text { 0.001*** } \\
(\mathbf{0 . 0 0 4 )}\end{array}$ & $\begin{array}{l}0.00003 \\
(0.938)\end{array}$ & $\begin{array}{l}0.0004 \\
(0.244)\end{array}$ & $\begin{array}{l}0.0001 \\
(0.619)\end{array}$ & $\begin{array}{l}-0.0002 \\
(0.585)\end{array}$ & $\begin{array}{l}\text { 0.001**** } \\
(0.000)\end{array}$ & $\begin{array}{l}\mathbf{0 . 0 0 1} * * * \\
(\mathbf{0 . 0 0 0 )}\end{array}$ \\
\hline Foreign Aid(-1) & $-0.0002 *$ & -0.00007 & $-0.001 * * *$ & $\overline{0.0009 * * *}$ & $-0.001 * * *$ & $-0.001 * * *$ & $-0.005^{* * * *}$ & $-0.005^{* * *}$ \\
\hline FDI(-1) & $\begin{array}{l}(\mathbf{0 . 0 5 7}) \\
0.0001 \\
(0.333)\end{array}$ & $\begin{array}{l}(0.609) \\
0.00008 \\
(0.734)\end{array}$ & $\begin{array}{l}(\mathbf{0 . 0 0 0 )}) \\
0.0004 \\
(0.223)\end{array}$ & $\begin{array}{l}(\mathbf{0 . 0 0 7}) \\
\mathbf{0 . 0 0 0 8}^{* * *} \\
(\mathbf{0 . 0 3 1})\end{array}$ & $\begin{array}{l}(0.000) \\
0.001 * * \\
(0.047)\end{array}$ & $\begin{array}{l}(0.000) \\
0.001 * * \\
(0.017)\end{array}$ & $\begin{array}{l}(\mathbf{0 . 0 0 0}) \\
0.0008 \\
(0.393)\end{array}$ & $\begin{array}{l}(0.000) \\
0.001 * \\
(0.054)\end{array}$ \\
\hline Net effects & 0.0115 & na & na & 0.0261 & 0.0446 & 0.0327 & na & na \\
\hline Within $\left(\mathrm{R}^{2}\right)$ & 0.468 & 0.409 & 0.552 & 0.539 & & & & \\
\hline $\begin{array}{l}\text { LR Chi-Square } \\
\text { Log Likelihood }\end{array}$ & & & & & $\begin{array}{l}\text { 316.84**** } \\
393.925\end{array}$ & $\begin{array}{l}\text { 315.12**** } \\
392.586\end{array}$ & $\begin{array}{l}\text { 200.96**** } \\
245.643\end{array}$ & $\begin{array}{l}\mathbf{2 2 2 . 6 2} * * * * \\
253.919\end{array}$ \\
\hline Fisher & $34.15 * * *$ & $23.80 * * *$ & $27.65 * * *$ & $25.97 * * *$ & & & & \\
\hline Countries & 42 & 40 & 28 & 28 & & & & \\
\hline Observations & 320 & 287 & 192 & 190 & 291 & 287 & 192 & 190 \\
\hline
\end{tabular}

***,***: significance levels of $10 \%, 5 \%$ and $1 \%$ respectively. na: not applicable because at least one estimated coefficient needed for the computation of net effects is not significant. The mean of mobile phone penetration is 24.428. The mean of internet penetration is 4.222. CO2mtpc: CO2 emissions (metric tons per capita). CO2inten: CO2 intensity (kg per kg of oil equivalent energy use). FDI: Foreign Direct Investment.

Table 2 presents findings from Fixed Effects regressions in two main panels and four sub-panels. Hence, Panel A on $\mathrm{CO}_{2}$ emissions per capita is sub-divided into Panel A1 on 'mobile phone'-oriented regressions and Panel A2 on 'internet'-oriented regressions while Panel $\mathrm{B}$ on $\mathrm{CO}_{2}$ intensity is sub-divided into Panel B1 on 'mobile phone'-oriented regressions and Panel B2 on 'internet'-oriented regressions. Whereas control variables used in the baseline regressions are included in these specifications, their estimated coefficients are not reported for lack of space. Net effects are also computed as explained earlier in the case of baseline regressions in Table 1. 
The following findings can be confirmed from Table 2. First, in Panel A1 on the 'mobile phone' and ' $\mathrm{CO}_{2}$ emissions per capita', positive net effects are apparent in English Common law, French Civil law, Oil-poor, Landlocked and Coastal countries. Second, in Panel A2 on the internet and ' $\mathrm{CO}_{2}$ emissions per capita', positive net effects are apparent in Low income, Oil-rich, Christian-dominated and Landlocked countries. Third, in Panel B1 on the 'mobile phone' and $\mathrm{CO}_{2}$ intensity, a positive net effect is visible exclusively in Landlocked countries. Fourth, in Panel B2 on the internet and $\mathrm{CO}_{2}$ intensity, positive net effects are observed in Low income, Oil-poor and Politically-stable countries whereas negative net effects are apparent in Christian-dominated, Coastal and politically-unstable countries.

Table 2: Comparative analysis with Fixed Effects

Dependent variable: Inequality Adjusted Human Development Index (IHDI)

Panel A: CO2 emissions per capita(CO2mtpc)

Panel A1: Mobile phone oriented regressions

\begin{tabular}{|c|c|c|c|c|c|c|c|c|c|c|c|c|}
\hline & \multicolumn{2}{|c|}{ Income Levels } & \multicolumn{2}{|c|}{ Legal Origins } & \multicolumn{2}{|c|}{ Resources } & \multicolumn{2}{|c|}{ Religion } & \multicolumn{2}{|c|}{ Openness to Sea } & \multicolumn{2}{|c|}{ Political Stability } \\
\hline & L.I & M.I & Eng. & Frch. & Oil-rich & Oil-poor & Christi & Islam & $\begin{array}{l}\text { Land } \\
\text { locked }\end{array}$ & $\begin{array}{l}\text { Unland } \\
\text { locked }\end{array}$ & Stable & Unstable \\
\hline Constant & $\begin{array}{l}0.443 * * * \\
(0.000)\end{array}$ & $\begin{array}{l}0.421 * * \\
(0.011)\end{array}$ & $\begin{array}{l}0.371 * * \\
(0.000)\end{array}$ & $\begin{array}{l}0.443^{* * * *} \\
(0.000)\end{array}$ & $\begin{array}{l}0.403 * * * \\
(0.000)\end{array}$ & $\begin{array}{l}0.439 * * * \\
(0.000)\end{array}$ & $\begin{array}{l}0.422 * * * * \\
(0.000)\end{array}$ & $\begin{array}{l}0.416 * * * \\
(0.000)\end{array}$ & $\begin{array}{l}0.367 * * * \\
(0.000)\end{array}$ & $\begin{array}{l}0.420 * * * \\
(0.000)\end{array}$ & $\begin{array}{l}0.440 * * * \\
(0.000)\end{array}$ & $\begin{array}{l}0.369 * * * \\
(0.000)\end{array}$ \\
\hline Mobile (Mob)(-1) & $\begin{array}{l}0.001 * * * \\
(0.000)\end{array}$ & $\begin{array}{l}0.0003 * * \\
(0.017)\end{array}$ & $\begin{array}{l}0.001 * * * \\
(0.000)\end{array}$ & $\begin{array}{l}0.0006 * * * * \\
(0.000)\end{array}$ & $\begin{array}{l}0.0005 \\
(0.105)\end{array}$ & $\begin{array}{l}0.0009 * * * \\
(0.000)\end{array}$ & $\begin{array}{l}0.0008 * * * \\
(0.000)\end{array}$ & $\begin{array}{l}0.0009 * * * * \\
(0.000)\end{array}$ & $\begin{array}{l}0.001 * * * \\
(0.000)\end{array}$ & $\begin{array}{l}0.0005 * * * \\
(0.000)\end{array}$ & $\begin{array}{l}\text { 0.0008**** } \\
(0.000)\end{array}$ & $\begin{array}{l}0.0008 \text { *** } \\
(0.000)\end{array}$ \\
\hline $\mathrm{CO} 2 \mathrm{mtpc}(-1)$ & $\begin{array}{l}-0.015 \\
(0.425)\end{array}$ & $\begin{array}{l}0.015 \\
(0.115)\end{array}$ & $\begin{array}{l}0.062 * * \\
(0.030)\end{array}$ & $\begin{array}{l}0.015^{*} \\
(0.052)\end{array}$ & $\begin{array}{l}0.148 * * \\
(0.048)\end{array}$ & $\begin{array}{l}0.018 * * \\
(0.032)\end{array}$ & $\begin{array}{l}0.028 \\
(0.189)\end{array}$ & $\begin{array}{l}0.005 \\
(0.416)\end{array}$ & $\begin{array}{l}0.107 * * \\
(0.024)\end{array}$ & $\begin{array}{l}0.014 * * \\
(0.047)\end{array}$ & $\begin{array}{l}0.009 \\
(0.290)\end{array}$ & $\begin{array}{l}0.053 \\
(0.248)\end{array}$ \\
\hline $\mathrm{CO} 2 \mathrm{mtpc} \times \operatorname{Mob}(-1)$ & $\begin{array}{l}-0.00004 \\
(0.461)\end{array}$ & $\begin{array}{l}-0.00002 \\
(0.570)\end{array}$ & $\begin{array}{l}-0.0001 * * \\
(0.020)\end{array}$ & $\begin{array}{l}0.00007 * * \\
(0.019)\end{array}$ & $(0.184)$ & $\begin{array}{l}0.0001 * * * \\
(\mathbf{0 . 0 0 0 )}\end{array}$ & $-0.0002 *$ & (0.000) & $\begin{array}{l}0.0004 * * * \\
(0.004)\end{array}$ & $\begin{array}{l}0.00007 * * \\
(0.010)\end{array}$ & $-0.0001 * * *$ & 0.0001 \\
\hline Control variables & Yes & Yes & Yes & Yes & Yes & Yes & Yes & Yes & Yes & Yes & Yes & Yes \\
\hline Net effects & na & na & 0.059 & 0.013 & na & 0.015 & na & na & 0.097 & 0.012 & na & na \\
\hline $\begin{array}{l}\text { Within } \\
\text { Fisher } \\
\text { Countries }\end{array}$ & $\begin{array}{l}0.522 \\
\mathbf{2 7 . 5 1} * * * \\
28\end{array}$ & $\begin{array}{l}0.513 \\
13.29 * * * \\
14\end{array}$ & $\begin{array}{l}0.606 \\
\mathbf{2 5 . 3 3} * * * \\
17\end{array}$ & $\begin{array}{l}0.412 \\
14.93 * * * \\
25\end{array}$ & $\begin{array}{l}0.388 \\
\mathbf{3 . 8 0} * * * \\
7\end{array}$ & $\begin{array}{l}0.529 \\
35.66 * * * \\
35\end{array}$ & $\begin{array}{l}0.439 \\
21.03 * * * \\
29\end{array}$ & $\begin{array}{l}0.678 \\
\mathbf{2 2 . 9 2} * * * \\
13\end{array}$ & $\begin{array}{l}0.623 \\
\mathbf{2 2 . 9 8} * * * \\
14\end{array}$ & $\begin{array}{l}0.510 \\
\mathbf{2 4 . 8 8} * * * \\
28\end{array}$ & $\begin{array}{l}0.517 \\
\mathbf{3 1 . 8 9} * * * \\
32\end{array}$ & $\begin{array}{l}0.436 \\
\mathbf{6 . 1 9} * * * \\
10\end{array}$ \\
\hline Observations & 211 & 109 & 139 & 181 & 56 & 264 & 224 & 96 & 118 & 202 & 247 & 73 \\
\hline
\end{tabular}

\begin{tabular}{|c|c|c|c|c|c|c|c|c|c|c|c|c|}
\hline & \multicolumn{12}{|c|}{ Panel A2: Internet oriented regressions } \\
\hline & \multicolumn{2}{|c|}{ Income Levels } & \multicolumn{2}{|c|}{ Legal Origins } & \multicolumn{2}{|c|}{ Resources } & \multicolumn{2}{|c|}{ Religion } & \multicolumn{2}{|c|}{ Openness to Sea } & \multicolumn{2}{|c|}{ Political Stability } \\
\hline & L.I & M.I & Eng. & Frch. & Oil-rich & Oil-poor & Christi & Islam & $\begin{array}{l}\text { Land } \\
\text { locked }\end{array}$ & $\begin{array}{l}\text { Unland } \\
\text { locked }\end{array}$ & Stable & Unstable \\
\hline Constant & $\begin{array}{l}0.408 * * * \\
(\mathbf{0 . 0 0 0 )}\end{array}$ & $\begin{array}{l}0.409 * * * \\
(0.000)\end{array}$ & $\begin{array}{l}0.454 * * * \\
(0.000)\end{array}$ & $\begin{array}{l}0.433 * * * \\
(\mathbf{0 . 0 0 0})\end{array}$ & $\begin{array}{l}0.429 * * * \\
(0.000)\end{array}$ & $\begin{array}{l}0.439 * * * \\
(\mathbf{0 . 0 0 0 )}\end{array}$ & $\begin{array}{l}0.403 * * * \\
(0.000)\end{array}$ & $\begin{array}{l}0.419 * * * \\
(0.000)\end{array}$ & $\begin{array}{l}0.411 * * * \\
(0.000)\end{array}$ & $\begin{array}{l}0.424 * * * \\
(0.000)\end{array}$ & $\begin{array}{l}0.444 * * * \\
(0.000)\end{array}$ & $\begin{array}{l}0.428 * * * \\
(0.000)\end{array}$ \\
\hline Internet (Inter)(-1) & $\begin{array}{l}0.005 * * * \\
(0.000)\end{array}$ & $\begin{array}{l}0.001 \\
(0.202)\end{array}$ & $\begin{array}{l}0.004 * * * \\
(0.000)\end{array}$ & $\begin{array}{l}\mathbf{0 . 0 0 3}{ }^{* * *} \\
(\mathbf{0 . 0 0 0})\end{array}$ & $\begin{array}{l}0.012 * * * \\
(0.004)\end{array}$ & $\begin{array}{l}0.004 * * * \\
(0.000)\end{array}$ & $\begin{array}{l}0.006 * * * \\
(0.000)\end{array}$ & $\begin{array}{l}0.002 * * * \\
(\mathbf{0 . 0 0 0})\end{array}$ & $\begin{array}{l}0.006 * * * \\
(0.000)\end{array}$ & $\begin{array}{l}0.003 * * * \\
(\mathbf{0 . 0 0 0})\end{array}$ & $\begin{array}{l}0.003 * * * \\
(0.000)\end{array}$ & $\begin{array}{l}0.004 * * * \\
(0.006)\end{array}$ \\
\hline $\mathrm{CO} 2 \mathrm{mtpc}(-1)$ & $\begin{array}{l}0.066 * * * \\
(0.003)\end{array}$ & $\begin{array}{l}0.018 \\
(0.405)\end{array}$ & $\begin{array}{l}0.025 * * * \\
(0.411)\end{array}$ & $\begin{array}{l}0.005 \\
(0.607)\end{array}$ & $\begin{array}{l}0.139 * * \\
(\mathbf{0 . 0 1 1})\end{array}$ & $\begin{array}{l}0.001 \\
(0.891)\end{array}$ & $\begin{array}{l}0.034 * \\
(0.096)\end{array}$ & $\begin{array}{l}-0.004 \\
(0.684)\end{array}$ & $\begin{array}{l}0.094 * \\
(0.091)\end{array}$ & $\begin{array}{l}-0.013 \\
(0.124)\end{array}$ & $\begin{array}{l}-0.009 \\
(0.376)\end{array}$ & $\begin{array}{l}0.007 \\
(0.939)\end{array}$ \\
\hline $\mathrm{CO} 2 \mathrm{mtpc} \times \operatorname{Inter}(-1)$ & $\begin{array}{l}-0.002 * * * \\
(0.000)\end{array}$ & $(0.735)$ & $\begin{array}{l}-0.0008 \\
(0.415)\end{array}$ & $\begin{array}{l}- \\
0.0008 * * * \\
(\mathbf{0 . 0 0 0 )}\end{array}$ & $-0.032 * *$ & $-0.001 * * *$ & $-0.002 * *$ & $-0.0005 * *$ & $(0.079)$ & $\begin{array}{l}- \\
\mathbf{0 . 0 0 0 8} * * * \\
(\mathbf{0 . 0 0 0 )}\end{array}$ & $-0.001 * * *$ & $\begin{array}{l}0.0003 \\
(0.881)\end{array}$ \\
\hline Control variables & Yes & Yes & Yes & Yes & Yes & Yes & Yes & Yes & Yes & Yes & Yes & Yes \\
\hline Net effects & 0.057 & na & na & na & 0.003 & na & 0.035 & na & 0.077 & na & na & na \\
\hline $\begin{array}{l}\text { Within } \\
\text { Fisher } \\
\text { Countries }\end{array}$ & $\begin{array}{l}0.450 \\
\mathbf{1 8 . 6 3} * * * \\
27\end{array}$ & $\begin{array}{l}0.550 \\
\mathbf{1 2 . 9 6}^{* * * *} \\
13\end{array}$ & $\begin{array}{l}0.498 \\
\mathbf{1 4 . 3 6}^{* * * *} \\
16\end{array}$ & $\begin{array}{l}0.443 \\
15.00 * * * \\
24\end{array}$ & $\begin{array}{l}0.578 \\
7.05 * * * \\
7\end{array}$ & $\begin{array}{l}0.429 \\
\mathbf{2 1 . 1 5}_{33} \text { **** }\end{array}$ & $\begin{array}{l}0.443 \\
\mathbf{1 9 . 0 4} * * * * \\
27\end{array}$ & $\begin{array}{l}0.496 \\
\mathbf{9 . 3 1} * * * * \\
13\end{array}$ & $\begin{array}{l}0.415 \\
\mathbf{8 . 6 3}^{* * * *} \\
13\end{array}$ & $\begin{array}{l}0.568 \\
\mathbf{2 7 . 9 0} \\
27\end{array}$ & $\begin{array}{l}0.497 \\
\mathbf{2 6 . 3 4} * * * \\
30\end{array}$ & 0.192 \\
\hline Observations & 193 & 94 & 124 & 163 & 50 & 237 & 201 & 86 & 105 & 182 & 223 & 64 \\
\hline
\end{tabular}




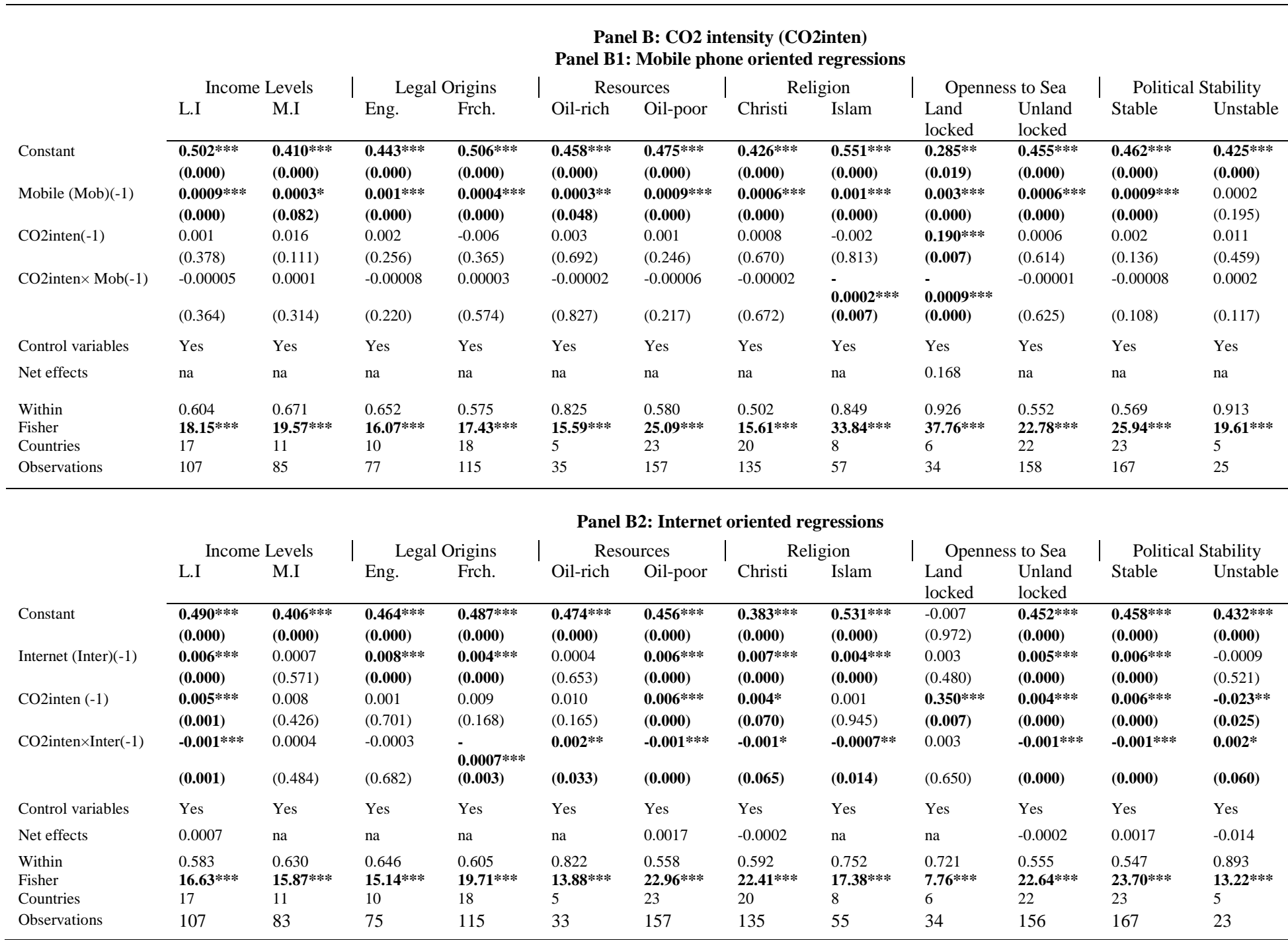

LI: Low Income countries. MI: Middle Income countries. Eng: English Common law countries. Frch: French Civil law countries. Oil-rich: Oil exporting countries. Oil-poor: Nonoil exporting countries. Christ: Christian-dominated countries. Islam: Islam-dominated countries. Landlocked: Landlocked countries. Coastal: Coastal countries. Stable: Politically stable countries. Unstable: Politically unstable countries. $\mathrm{CO} 2 \mathrm{mtpc}$ : $\mathrm{CO} 2$ emissions (metric tons per capita). CO2inten: $\mathrm{CO} 2$ intensity (kg per kg of oil equivalent energy use). *******: significance levels of $10 \%, 5 \%$ and $1 \%$ respectively. na: not applicable because at least one estimated coefficient needed for the computation of net effects is not significant. The mean of mobile phone penetration is 24.428. The mean of internet penetration is 4.222.

Table 3 presents findings from Tobit regressions in two main panels and four subpanels. Like in Table 2, Panel A on $\mathrm{CO}_{2}$ emissions per capita is sub-divided into Panel $\mathrm{A} 1$ on 'mobile phone'-oriented regressions and Panel A2 on 'internet'-oriented regressions while Panel B on $\mathrm{CO}_{2}$ intensity is sub-divided into Panel B1 on 'mobile phone'-oriented regressions and Panel B2 on 'internet'-oriented regressions. Similarly, whereas control variables used in the baseline regressions are included in the specifications, their estimated coefficients are not reported for lack of space. Reporting the control variables will increase the manuscript length by about four pages without changing the main findings because control variables are not the independent variables of particular interest. This approach of not disclosing control variables in 
subsequent regressions is consistent with standard practice in studies by (Efobi et al. (2018) and Ssozi and Asongu (2016).

Net effects are also computed as in the baseline regressions in Table 1. The following findings are notable. First, in Panel A1 on the 'mobile phone' and ' $\mathrm{CO}_{2}$ emissions per capita', positive net effects are noticeable with the exceptions of Low Income, Christian-dominated, Coastal and Political-unstable countries. Second, in Panel A2 on the internet and ' $\mathrm{CO}_{2}$ emissions per capita', positive net effects also dominate with the exceptions of Low Income, Christian-oriented, Islam-dominated, Coastal and Politically-unstable countries. Third, in Panel $\mathrm{B} 1$ on the 'mobile phone' and $\mathrm{CO}_{2}$ intensity, positive net effects are again reported exclusively in Islam-oriented, Landlocked and Politically-unstable countries. Fourth, in Panel B2 on the internet and $\mathrm{CO}_{2}$ intensity, positive net effects are observed exclusively in Low Income, Middle Income and Political-unstable countries.

When the comparative findings in Table 2 and Table 3 are compared and contrasted horizontally and vertically, we can conclude that inclusive human development in English Common law countries, Middle Income countries and Oil-rich countries are more responsive to the modulating impact of ICT on potentially harmful $\mathrm{CO}_{2}$ emissions compared to respectively, French Civil law countries, Low Income countries and Oil-poor countries.

Table 3: Comparative analysis with Tobit regressions

\begin{tabular}{|c|c|c|c|c|c|c|c|c|c|c|c|c|}
\hline & \multicolumn{12}{|c|}{ Dependent variable: Inequality Adjusted Human Development Index (IHDI) } \\
\hline & \multicolumn{12}{|c|}{$\begin{array}{l}\text { Panel A: CO2 emissions per capita(CO2mtpc) } \\
\text { Panel A1: Mobile phone oriented regressions }\end{array}$} \\
\hline & \multicolumn{2}{|c|}{ Income Levels } & \multicolumn{2}{|c|}{ Legal Origins } & \multicolumn{2}{|c|}{ Resources } & \multicolumn{2}{|c|}{ Religion } & \multicolumn{2}{|c|}{ Openness to Sea } & \multicolumn{2}{|c|}{ Political Stability } \\
\hline & L.I & M.I & Eng. & Frch. & Oil-rich & Oil-poor & Christi & Islam & $\begin{array}{l}\text { Land } \\
\text { locked }\end{array}$ & $\begin{array}{l}\text { Unland } \\
\text { locked }\end{array}$ & Stable & Unstable \\
\hline Constant & $\begin{array}{l}\mathbf{0 . 4 3 9} * * * * \\
(\mathbf{0 . 0 0 0})\end{array}$ & $\begin{array}{l}0.398 * * * \\
(0.000)\end{array}$ & $\begin{array}{l}0.443 * * * \\
(0.000)\end{array}$ & $\begin{array}{l}0.393 * * * \\
(0.000)\end{array}$ & $\begin{array}{l}0.274 * * * \\
(0.000)\end{array}$ & $\begin{array}{l}0.469 * * * \\
(0.000)\end{array}$ & $\begin{array}{l}0.398 * * * \\
(0.000)\end{array}$ & $\begin{array}{l}0.589 * * * \\
(0.000)\end{array}$ & $\begin{array}{l}0.459 * * * \\
(\mathbf{0 . 0 0 0})\end{array}$ & $\begin{array}{l}0.440 * * * \\
(0.000)\end{array}$ & $\begin{array}{l}0.370 * * * \\
(\mathbf{0 . 0 0 0})\end{array}$ & $\begin{array}{l}0.493 * * * \\
(0.000)\end{array}$ \\
\hline Mobile (Mob)(-1) & $\begin{array}{l}\text { 0.001**** } \\
(\mathbf{0 . 0 0 0 )}\end{array}$ & $\begin{array}{l}\text { 0.001*** } \\
(0.000)\end{array}$ & $\begin{array}{l}0.002 * * * \\
(\mathbf{0 . 0 0 0 )}\end{array}$ & $\begin{array}{l}\text { 0.001*** } \\
(\mathbf{0 . 0 0 0 )}\end{array}$ & $\begin{array}{l}0.004 * * * \\
(0.000)\end{array}$ & $\begin{array}{l}0.001 * * * \\
(0.000)\end{array}$ & $\begin{array}{l}\mathbf{0 . 0 0 1} * * * \\
(\mathbf{0 . 0 0 0 )})\end{array}$ & $\begin{array}{l}0.001 * * * \\
(0.000)\end{array}$ & $\begin{array}{l}\mathbf{0 . 0 0 2} * * * \\
(\mathbf{0 . 0 0 0 )}\end{array}$ & $\begin{array}{l}\mathbf{0 . 0 0 1} * * * \\
(\mathbf{0 . 0 0 0 )}\end{array}$ & $\begin{array}{l}\text { 0.001*** } \\
(\mathbf{0 . 0 0 0 )}\end{array}$ & $\begin{array}{l}\text { 0.001**** } \\
(0.006)\end{array}$ \\
\hline CO2mtpc(-1) & $\begin{array}{l}0.020 \\
(0.100)\end{array}$ & $\begin{array}{l}0.082 * * * \\
(0.000)\end{array}$ & $\begin{array}{l}0.087 * * * \\
(0.000)\end{array}$ & $\begin{array}{l}0.051^{* * * *} \\
(0.000)\end{array}$ & $\begin{array}{l}0.764 * * * \\
(0.000)\end{array}$ & $\begin{array}{l}0.048 * * * \\
(0.000)\end{array}$ & $\begin{array}{l}\mathbf{0 . 0 8 0} * * * \\
(\mathbf{0 . 0 0 0})\end{array}$ & $\begin{array}{l}0.021 * * \\
(0.029)\end{array}$ & $\begin{array}{l}0.105 * * * \\
(0.000)\end{array}$ & $\begin{array}{l}0.021 * * \\
(0.042)\end{array}$ & $\begin{array}{l}0.073 * * * \\
(0.000)\end{array}$ & $\begin{array}{l}0.040 * * \\
(0.021)\end{array}$ \\
\hline $\mathrm{CO} 2 \mathrm{mtpc} \times \operatorname{Mob}(-1)$ & $\begin{array}{l}0.0005 * * * \\
(\mathbf{0 . 0 0 0 )}\end{array}$ & $\begin{array}{l}- \\
\mathbf{0 . 0 0 0 5} * * * * \\
(0.000)\end{array}$ & $-0.0002 *$ & $-0.0002 * *$ & $\begin{array}{l}-0.013 * * * \\
(0.000)\end{array}$ & $\begin{array}{l}\mathbf{0 . 0 0 0 3} * * * \\
(\mathbf{0 . 0 0 0 )}\end{array}$ & $(0.719)$ & $\begin{array}{l}-0.0002 * * \\
(0.029)\end{array}$ & $-0.0005 * *$ & -0.0001 & $-0.0004 * * *$ & 0.00001 \\
\hline Control variables & Yes & Yes & Yes & Yes & Yes & Yes & Yes & Yes & Yes & Yes & Yes & Yes \\
\hline Net effects & na & 0.069 & 0.082 & 0.046 & 0.446 & 0.040 & na & 0.016 & 0.092 & na & 0.063 & na \\
\hline $\begin{array}{l}\text { LR Chi-Square } \\
\text { Log Likelihood }\end{array}$ & $\begin{array}{l}\mathbf{2 0 7 . 8 3}^{* * * *} \\
263.714\end{array}$ & $\begin{array}{l}\text { 155.14**** } \\
147.653\end{array}$ & $\begin{array}{l}\mathbf{1 3 7 . 8 7} * * * \\
184.721\end{array}$ & $\begin{array}{l}\mathbf{2 6 2 . 6 7 * * *} \\
249.525\end{array}$ & $\begin{array}{l}\text { 83.66**** } \\
100.787\end{array}$ & $\begin{array}{l}\text { 281.96**** } \\
319.251\end{array}$ & $\begin{array}{l}\mathbf{1 8 7 . 2 5} \text { **** } \\
294.305\end{array}$ & $\begin{array}{l}\mathbf{1 6 1 . 5 3} * * * * \\
128.004\end{array}$ & $\begin{array}{l}\text { 216.57**** } \\
199.931\end{array}$ & $\begin{array}{l}\text { 191.69**** } \\
241.542\end{array}$ & $\begin{array}{l}322.98 * * * \\
335.906\end{array}$ & $\begin{array}{l}\mathbf{7 0 . 9 9} * * * \\
101.136\end{array}$ \\
\hline Observations & 193 & 98 & 127 & 164 & 52 & 239 & 202 & 89 & 106 & 185 & 225 & 66 \\
\hline
\end{tabular}




\begin{tabular}{|c|c|c|c|c|c|c|c|c|c|c|c|c|}
\hline & \multicolumn{12}{|c|}{ Panel A2: Internet oriented regressions } \\
\hline & \multicolumn{2}{|c|}{ Income Levels } & \multicolumn{2}{|c|}{ Legal Origins } & \multicolumn{2}{|c|}{ Resources } & \multicolumn{2}{|c|}{ Religion } & \multicolumn{2}{|c|}{ Openness to Sea } & \multicolumn{2}{|c|}{ Political Stability } \\
\hline & L.I & M.I & Eng. & Frch. & Oil-rich & Oil-poor & Christi & Islam & $\begin{array}{l}\text { Land } \\
\text { locked }\end{array}$ & $\begin{array}{l}\text { Unland } \\
\text { locked }\end{array}$ & Stable & Unstable \\
\hline Constant & $\begin{array}{l}0.485 * * * \\
(0.000)\end{array}$ & $\begin{array}{l}0.390 * * * \\
(0.000)\end{array}$ & $\begin{array}{l}0.433 * * * \\
(0.000)\end{array}$ & $\begin{array}{l}0.406 * * * \\
(0.000)\end{array}$ & $\begin{array}{l}0.247 * * * \\
(0.000)\end{array}$ & $\begin{array}{l}0.479 * * * \\
(0.000)\end{array}$ & $\begin{array}{l}0.400 * * * \\
(0.000)\end{array}$ & $\begin{array}{l}0.549 * * * \\
(0.000)\end{array}$ & $\begin{array}{l}0.420 * * * \\
(0.000)\end{array}$ & $\begin{array}{l}0.394 * * * \\
(0.000)\end{array}$ & $\begin{array}{l}0.369 * * * \\
(0.000)\end{array}$ & $\begin{array}{l}0.488 * * * \\
(0.000)\end{array}$ \\
\hline Internet (Inter)(-1) & $\begin{array}{l}0.008 * * * * \\
(0.000)\end{array}$ & $\begin{array}{l}0.008 * * * \\
(0.001)\end{array}$ & $\begin{array}{l}0.012 * * * \\
(0.000)\end{array}$ & $\begin{array}{l}0.006 * * * \\
(0.000)\end{array}$ & $\begin{array}{l}0.017 * * * \\
(0.000)\end{array}$ & $\begin{array}{l}0.033 * * * \\
(0.000)\end{array}$ & $\begin{array}{l}0.085 * * * \\
(0.000)\end{array}$ & $\begin{array}{l}0.006 * * * \\
(0.001)\end{array}$ & $\begin{array}{l}0.012 * * * \\
(0.000)\end{array}$ & $\begin{array}{l}0.007 * * * \\
(\mathbf{0 . 0 0 0 )}\end{array}$ & $\begin{array}{l}0.006 * * * \\
(0.000)\end{array}$ & $\begin{array}{l}\text { 0.006* } \\
(\mathbf{0 . 0 8 5 )}\end{array}$ \\
\hline $\mathrm{CO} 2 \mathrm{mtpc}(-1)$ & $\begin{array}{l}-0.00001 \\
(0.999)\end{array}$ & $\begin{array}{l}0.094 * * * \\
(0.000)\end{array}$ & $\begin{array}{l}0.114 * * * \\
(0.000)\end{array}$ & $\begin{array}{l}0.056 * * * \\
(0.000)\end{array}$ & $\begin{array}{l}0.728 * * * \\
(0.000)\end{array}$ & $\begin{array}{l}-0.001 * * * \\
(0.001)\end{array}$ & $\begin{array}{l}0.001 \\
(0.685)\end{array}$ & $\begin{array}{l}-0.011 \\
(0.248)\end{array}$ & $\begin{array}{l}0.134 * * * \\
(0.000)\end{array}$ & $\begin{array}{l}-0.015 \\
(0.126)\end{array}$ & $\begin{array}{l}0.084 * * * \\
(0.000)\end{array}$ & $\begin{array}{l}0.039 \\
(0.314)\end{array}$ \\
\hline $\mathrm{CO} 2 \mathrm{mtp} \times \mathrm{Inter}(-1)$ & $\begin{array}{l}0.0007 \\
(0.414)\end{array}$ & $\begin{array}{l}-0.002 * * * \\
(0.000)\end{array}$ & $\begin{array}{l}-0.008 * * * \\
(0.000)\end{array}$ & $\begin{array}{l}-0.001 * * * \\
(0.004)\end{array}$ & $\begin{array}{l}-0.069 * * * \\
(0.000)\end{array}$ & $\begin{array}{l}-0.001 * * * \\
(0.000)\end{array}$ & $\begin{array}{l}-0.000 \\
0002 \\
(0.999)\end{array}$ & $\begin{array}{l}0.0003 \\
(0.493)\end{array}$ & $\begin{array}{l}-0.017 * * \\
(0.013)\end{array}$ & $\begin{array}{l}0.0006 \\
(0.134)\end{array}$ & $\begin{array}{l}-0.001 * * * \\
(0.000)\end{array}$ & $\begin{array}{l}-0.001 \\
(0.769)\end{array}$ \\
\hline Control variables & Yes & Yes & Yes & Yes & Yes & Yes & Yes & Yes & Yes & Yes & Yes & Yes \\
\hline Net effects & na & 0.085 & 0.080 & 0.051 & 0.436 & -0.005 & na & na & 0.062 & na & 0.079 & na \\
\hline $\begin{array}{l}\text { LR Chi-Square } \\
\text { Log Likelihood }\end{array}$ & $\begin{array}{l}230.00 * * * \\
274.800\end{array}$ & $\begin{array}{l}140.18 * * * \\
139.280\end{array}$ & $\begin{array}{l}147.94 * * * \\
185.965\end{array}$ & $\begin{array}{l}250.57 * * * \\
245.751\end{array}$ & $\begin{array}{l}114.99 * * * \\
113.089\end{array}$ & $\begin{array}{l}291.91 * * * \\
325.964\end{array}$ & $\begin{array}{l}186.04 * * * \\
292.665\end{array}$ & $\begin{array}{l}183.08 * * * \\
137.708\end{array}$ & $\begin{array}{l}238.10 * * * \\
209.536\end{array}$ & $\begin{array}{l}235.89 * * * \\
263.492\end{array}$ & $\begin{array}{l}323.44 * * * \\
337.860\end{array}$ & $\begin{array}{l}\text { 63.32**** } \\
94.781\end{array}$ \\
\hline Observations & 193 & 94 & 124 & 163 & 50 & 237 & 201 & 86 & 105 & 182 & 223 & 64 \\
\hline
\end{tabular}

Panel B: CO2 intensity (CO2inten) Panel B1: Mobile phone oriented regressions

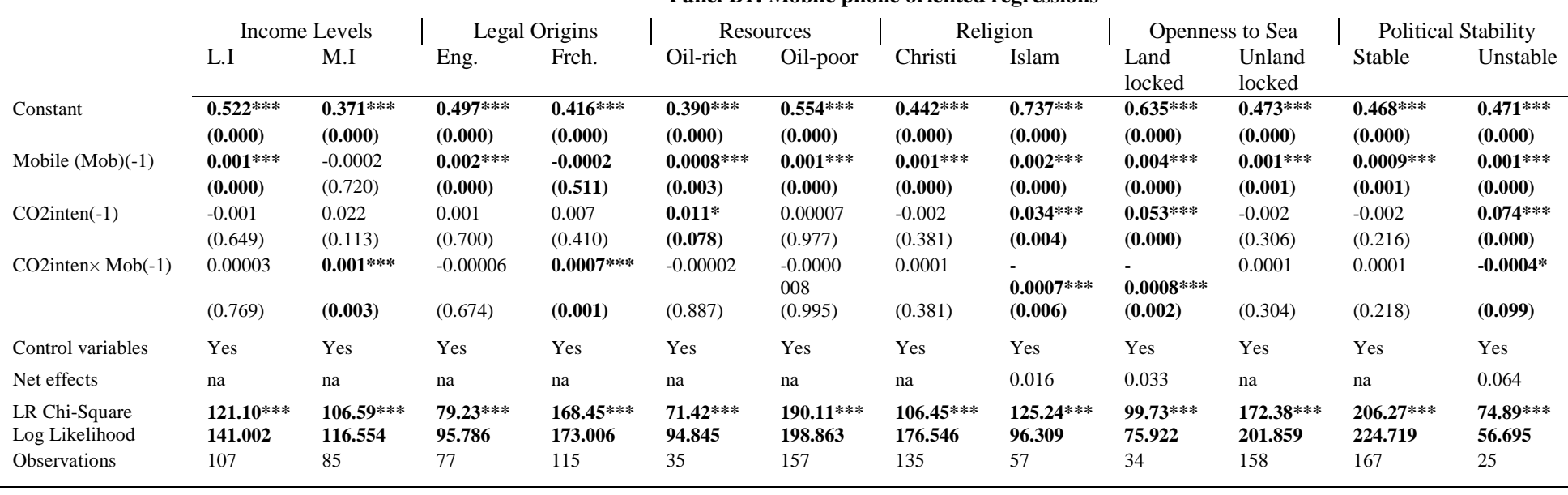

\begin{tabular}{|c|c|c|c|c|c|c|c|c|c|c|c|c|}
\hline & \multicolumn{12}{|c|}{ Panel B2: Internet oriented regressions } \\
\hline & \multicolumn{2}{|c|}{ Income Levels } & \multicolumn{2}{|c|}{ Legal Origins } & \multicolumn{2}{|c|}{ Resources } & \multicolumn{2}{|c|}{ Religion } & \multicolumn{2}{|c|}{ Openness to Sea } & \multicolumn{2}{|c|}{ Political Stability } \\
\hline & L.I & M.I & Eng. & Frch. & Oil-rich & Oil-poor & Christi & Islam & $\begin{array}{l}\text { Land } \\
\text { locked }\end{array}$ & $\begin{array}{l}\text { Unland } \\
\text { locked }\end{array}$ & Stable & Unstable \\
\hline Constant & $\begin{array}{l}0.501 * * * \\
(0.000)\end{array}$ & $\begin{array}{l}0.390 * * * \\
(0.000)\end{array}$ & $\begin{array}{l}0.524 * * * \\
(0.000)\end{array}$ & $\begin{array}{l}0.404 * * * \\
(0.000)\end{array}$ & $\begin{array}{l}0.366 * * * \\
(0.000)\end{array}$ & $\begin{array}{l}\mathbf{0 . 5 3 3} * * * \\
(\mathbf{0 . 0 0 0 )}\end{array}$ & $\begin{array}{l}0.448 * * * \\
(0.000)\end{array}$ & $\begin{array}{l}\mathbf{0 . 6 3 3} * * * \\
(\mathbf{0 . 0 0 0 )}\end{array}$ & $\begin{array}{l}0.541 * * * \\
(0.000)\end{array}$ & $\begin{array}{l}0.418 * * * \\
(0.000)\end{array}$ & $\begin{array}{l}\mathbf{0 . 4 8 3} * * * \\
(0.000)\end{array}$ & $\begin{array}{l}\text { 0.450*** } \\
(0.000)\end{array}$ \\
\hline Internet (Inter)(-1) & $\begin{array}{l}0.004 * * \\
(0.019)\end{array}$ & $\begin{array}{l}-0.002 \\
(0.544)\end{array}$ & $\begin{array}{l}0.014 * * * \\
(0.000)\end{array}$ & $\begin{array}{l}-0.0002 \\
(0.908)\end{array}$ & $\begin{array}{l}0.002 \\
(0.448)\end{array}$ & $\begin{array}{l}0.007 * * * \\
(0.000)\end{array}$ & $\begin{array}{l}0.008 * * * \\
(0.002)\end{array}$ & $\begin{array}{l}0.006 * * * \\
(0.004)\end{array}$ & $\begin{array}{l}0.005 \\
(0.433)\end{array}$ & $\begin{array}{l}0.006 * * * \\
(\mathbf{0 . 0 0 2})\end{array}$ & $\begin{array}{l}0.003 * \\
(0.071)\end{array}$ & $\begin{array}{l}0.010 * * * \\
(0.007)\end{array}$ \\
\hline CO2inten $(-1)$ & $\begin{array}{l}-\mathbf{0 . 0 0 7} * * * \\
(0.003)\end{array}$ & $\begin{array}{l}0.030 * * \\
(0.022)\end{array}$ & $\begin{array}{l}0.002 \\
(0.673)\end{array}$ & $\begin{array}{l}0.007 \\
(0.376)\end{array}$ & $\begin{array}{l}0.002 \\
(0.848)\end{array}$ & $\begin{array}{l}0.0006 \\
(0.807)\end{array}$ & $\begin{array}{l}0.00001 \\
(0.998)\end{array}$ & $\begin{array}{l}0.027 * * \\
(0.022)\end{array}$ & $\begin{array}{l}0.044 \\
(0.214)\end{array}$ & $\begin{array}{l}-0.003 \\
(0.201)\end{array}$ & $\begin{array}{l}-0.003 \\
(0.137)\end{array}$ & $\begin{array}{l}0.057 * * \\
(0.042)\end{array}$ \\
\hline CO2inten $\times$ Inter(-1) & $\begin{array}{l}0.002 * * * \\
(0.004)\end{array}$ & $\begin{array}{l}0.003 * \\
(0.093)\end{array}$ & $\begin{array}{l}-0.0007 \\
(0.664)\end{array}$ & $\begin{array}{l}0.002 * * \\
(0.003)\end{array}$ & $\begin{array}{l}0.0008 \\
(0.696)\end{array}$ & $\begin{array}{l}-0.0002 \\
(0.798)\end{array}$ & $\begin{array}{l}-0.00007 \\
(0.959)\end{array}$ & $\begin{array}{l}-0.0004 \\
(0.620)\end{array}$ & $\begin{array}{l}0.002 \\
(0.700)\end{array}$ & $\begin{array}{l}0.001 \\
(0.205)\end{array}$ & $\begin{array}{l}0.001 \\
(0.151)\end{array}$ & $\begin{array}{l}-0.006 * * \\
(0.045)\end{array}$ \\
\hline Control variables & Yes & Yes & Yes & Yes & Yes & Yes & Yes & Yes & Yes & Yes & Yes & Yes \\
\hline Net effects & 0.001 & 0.042 & na & na & na & na & na & na & na & na & na & 0.031 \\
\hline $\begin{array}{l}\text { LR Chi-Square } \\
\text { Log Likelihood }\end{array}$ & $\begin{array}{l}155.75^{* * * *} \\
158.326\end{array}$ & $\begin{array}{l}94.88 * * * \\
108.149\end{array}$ & $\begin{array}{l}\text { 73.83*** } \\
\mathbf{9 0 . 5 8 2}\end{array}$ & $\begin{array}{l}174.27 * * * \\
175.918\end{array}$ & $\begin{array}{l}\text { 47.46*** } \\
\mathbf{7 8 . 4 8 2}\end{array}$ & $\begin{array}{l}212.35 * * * \\
209.981\end{array}$ & $\begin{array}{l}100.02 * * * \\
173.330\end{array}$ & $\begin{array}{l}124.93 * * * \\
94.176\end{array}$ & $\begin{array}{l}51.33 * * * \\
51.726\end{array}$ & $\begin{array}{l}216.07 * * * \\
221.189\end{array}$ & $\begin{array}{l}206.56 * * * \\
224.862\end{array}$ & $\begin{array}{l}62.86 * * * \\
47.845\end{array}$ \\
\hline Observations & 107 & 83 & 75 & 115 & 33 & 157 & 135 & 55 & 34 & 156 & 167 & 23 \\
\hline
\end{tabular}

LI: Low Income countries. MI: Middle Income countries. Eng: English Common law countries. Frch: French Civil law countries. Oil-rich: Oil exporting countries. Oil-poor: Nonoil exporting countries. Christ: Christian-dominated countries. Islam: Islam-dominated countries. Landlocked: Landlocked countries. Coastal: Coastal countries. Stable: Politically stable countries. Unstable: Politically unstable countries. $\mathrm{CO} 2 \mathrm{mtpc}$ : $\mathrm{CO} 2$ emissions (metric tons per capita). CO2inten: $\mathrm{CO} 2$ intensity (kg per kg of oil equivalent energy use). ***,***: significance levels of $10 \%, 5 \%$ and $1 \%$ respectively. na: not applicable because at least one estimated coefficient needed for the computation of net effects is not significant. The mean of mobile phone penetration is 24.428 . The mean of internet penetration is 4.222 . 
The established comparative impacts of the fundamental characteristics are compatible with the underpinnings covered in Section 2. In what follows, we discuss the theoretical and practical implications of the findings.

On the practical aspect, we uncovered that ICT can considerably enhance inclusive human development by mitigating the potential constraints and economic costs linked to $\mathrm{CO}_{2}$ emissions. The importance of ICT in reducing $\mathrm{CO}_{2}$ emissions is broadly supported by a stream of literature. This maintains that through efficient infrastructure network opportunities, ICT can reduce the need for transportation with corresponding unit cost linked with economic activities (see Gille et al., 2002; Esselaar et al., 2007; Gilwald \& Stork, 2008; Gutierrez et al., 2009). For instance, a mobile phone connected to the internet can be employed as a medium of communication and hence reduce the need for physical meetings that require transportation costs and corresponding $\mathrm{CO}_{2}$ emissions. The income saved can subsequently be used for amenities that improve human development.

Consequently, we propose that in the post-2015 sustainable development era, ICT can be leveraged by policymakers in underdeveloped regions like SSA to address challenges of climate change and exclusive human development. As we noted earlier, the decision to single out the SSA sub-continent in this study follows from the fact that: (i) extreme poverty has been growing in the sub-region despite a more than two decades of growth resurgence and (ii) although SSA is reported to have the greatest opportunities for ICT penetration, it is projected to be the most affected by the negative externalities of global warming and climate change. Given that $\mathrm{CO}_{2}$ emissions represent about 75 percent of global greenhouse gas emissions, it is pertinent for policymakers in our countries of study to address issues pertaining to quality and affordability of ICT by the poorest population. More specifically, schemes encouraging universal coverage, low pricing and the modernisation of ICT network should be sported by SSA government and their development finance sponsors. As remarked by Chemutai (2009), these policy initiatives are in accordance with the view of the World Trade Organisation (WTO) that innovative and reliable communication systems are essential to achieving environmental sustainability. The empirical findings established in this study have shown that the effectiveness of such an improvement in ICT infrastructure is more pronounced in poor countries like those in the SSA region.

The theoretical contribution of the findings in this study primarily lies in the demonstration that ICT could be employed as an information sharing tool to lower informational rents associated with environmental degradation. This insight broadly conforms 
with the mission statement of information sharing offices (public credit registries and private credit bureaus) which is to lower information asymmetry for financial intermediaries (see Tchamyou \& Asongu, 2017; Tchamyou, 2018b; Boateng et al., 2018). Any associated increase in credit extension to the private sector should raise investment in those activities which stimulate inclusive human development.

\section{Conclusion and future research directions}

This study examines how information and communication technology (ICT) dampens the possible harmful effects of environmental degradation in order to promote inclusive human development in 44 Sub-Saharan African countries using data from 2000-2012. ICT is measured with internet and mobile phone penetration rates whereas environmental deprivation is captured by $\mathrm{CO}_{2}$ emissions per capita and $\mathrm{CO}_{2}$ intensity. The empirical evidence is based on Fixed Effects and Tobit regressions. In order to increase the policy relevance of this study, the dataset is decomposed into fundamental characteristics of inclusive development and environmental degradation based on income levels (Low income versus (vs.) Middle income); legal origins (English Common law vs. French Civil law); religious domination (Christianity vs. Islam); openness to sea (Landlocked vs. Coastal); resource-wealth (Oil-rich vs. Oil-poor) and political stability (Stable vs. Unstable).

Baseline findings broadly support the hypothesis that ICT can be employed to alleviate the potentially damaging effect of environmental pollution on inclusive human development. When the analysis is extended with fundamental characteristics, we uncovered that the estimated moderating impact of ICT on $\mathrm{CO}_{2}$ emissions is greater in English Common law countries, Middle income countries and Oil-wealthy countries than in French Civil law countries, Low income countries and Oil-poor countries, respectively.

Future inquiries can improve the existing literature by assessing how the connection between ICT, $\mathrm{CO}_{2}$ emissions and inclusive development are relevant to individual country scenarios. Within these country-specific contexts, measures of environmental degradation other than $\mathrm{CO}_{2}$ emissions should be considered in order to test the robustness of our results to individual country outcomes. These recommendations for future research build on the caveat that policy implications which are limited to the fundamental characteristics employed in this paper are somewhat general. 


\section{Appendices}

Appendix 1: Definitions of variables

\begin{tabular}{|c|c|c|c|}
\hline Variables & Signs & Definitions of variables (Measurements) & Sources \\
\hline $\begin{array}{l}\text { Inclusive } \\
\text { development }\end{array}$ & IHDI & Inequality Adjusted Human Development Index & UNDP \\
\hline $\mathrm{CO}_{2}$ per capita & $\mathrm{CO} 2 \mathrm{mtpc}$ & $\mathrm{CO}_{2}$ emissions (metric tons per capita) & $\begin{array}{l}\text { World Bank } \\
\text { (WDI) }\end{array}$ \\
\hline $\begin{array}{l}\mathrm{CO}_{2} \text { from electricity } \\
\text { and heat }\end{array}$ & CO2elehepro & $\begin{array}{l}\mathrm{CO}_{2} \text { emissions from electricity and heat production, total } \\
\text { (\% of total fuel combustion) }\end{array}$ & $\begin{array}{l}\text { World Bank } \\
\text { (WDI) }\end{array}$ \\
\hline $\begin{array}{l}\mathrm{CO}_{2} \text { from liquid } \\
\text { fuel }\end{array}$ & CO2lfcon & $\mathrm{CO}_{2}$ emissions from liquid fuel consumption (\% of total) & $\begin{array}{l}\text { World Bank } \\
\text { (WDI) }\end{array}$ \\
\hline $\mathrm{CO}_{2}$ intensity & CO2inten & $\mathrm{CO}_{2}$ intensity ( $\mathrm{kg}$ per $\mathrm{kg}$ of oil equivalent energy use) & $\begin{array}{l}\text { World Bank } \\
\text { (WDI) }\end{array}$ \\
\hline Internet & Internet & Internet penetration (per 100 people) & $\begin{array}{l}\text { World Bank } \\
\text { (WDI) }\end{array}$ \\
\hline Mobile phones & Mobile & Mobile phone subscriptions (per 100 people) & $\begin{array}{l}\text { World Bank } \\
\text { (WDI) }\end{array}$ \\
\hline Educational Quality & Educ & Pupil teacher ratio in Primary Education & $\begin{array}{l}\text { World Bank } \\
\text { (WDI) }\end{array}$ \\
\hline Foreign Aid & Aid & Total Official Development Assistance (\% of GDP) & $\begin{array}{l}\text { World Bank } \\
\text { (WDI) }\end{array}$ \\
\hline Private Credit & Credit & $\begin{array}{l}\text { Private credit by deposit banks and other financial } \\
\text { institutions (\% of } \\
\text { GDP) }\end{array}$ & $\begin{array}{l}\text { World Bank } \\
\text { (WDI) }\end{array}$ \\
\hline Foreign investment & FDI & Foreign Direct Investment inflows (\% of GDP) & $\begin{array}{l}\text { World Bank } \\
\text { (WDI) }\end{array}$ \\
\hline
\end{tabular}

WDI: World Development Indicators. UNDP: United Nations Development Programme.

Appendix 2: Summary statistics (2000-2012)

\begin{tabular}{lccccc}
\hline & Mean & SD & Minimum & Maximum & Observations \\
\cline { 2 - 5 } Inequality Adj. Human & 0.450 & 0.110 & 0.219 & 0.768 & 431 \\
Development & & & & & 525 \\
Mobile phone penetration & 24.428 & 28.535 & 0.000 & 147.202 & 521 \\
Internet Penetration & 4.222 & 6.618 & 0.005 & 43.605 & 567 \\
$\mathrm{CO}_{2}$ per capita & 0.901 & 1.820 & 0.016 & 10.093 & 321 \\
$\mathrm{CO}_{2}$ intensity & 2.044 & 6.449 & 0.058 & 77.586 & 425 \\
Educational Quality & 43.784 & 14.731 & 12.466 & 100.236 & 458 \\
Private Credit & 19.142 & 23.278 & 0.550 & 149.78 & 531 \\
Foreign aid & 11.944 & 14.712 & -0.253 & 181.187 & 529 \\
Foreign direct investment & 5.381 & 8.834 & -6.043 & 91.007 & \\
\hline S.D: Standard Deviation. Adj: Adjusted. & & & & &
\end{tabular}


Appendix 3: Correlation matrix (uniform sample size: 171)

\begin{tabular}{|c|c|c|c|c|c|c|c|c|c|}
\hline \multicolumn{2}{|c|}{$\mathrm{CO}_{2}$ emissions dynamics } & \multicolumn{4}{|c|}{ Control variables } & \multicolumn{2}{|c|}{ ICT } & \multirow[b]{2}{*}{ IHDI } & \multirow[b]{3}{*}{$\mathrm{CO} 2 \mathrm{mtpc}$} \\
\hline $\mathrm{CO} 2 \mathrm{mtpc}$ & CO2inten & Educ & Credit & Aid & FDI & Mobile & Internet & & \\
\hline \multirow[t]{9}{*}{1.000} & 0.773 & -0.441 & 0.851 & -0.370 & -0.101 & 0.474 & 0.438 & 0.616 & \\
\hline & 1.000 & -0.542 & 0.702 & -0.486 & -0.181 & 0.485 & 0.543 & 0.740 & CO2inten \\
\hline & & 1.000 & -0.456 & 0.512 & 0.151 & -0.338 & -0.417 & -0.499 & Educ \\
\hline & & & 1.000 & -0.321 & -0.181 & 0.518 & 0.642 & 0.616 & Credit \\
\hline & & & & 1.000 & 0.114 & -0.286 & -0.321 & -0.629 & Aid \\
\hline & & & & & 1.000 & 0.119 & -0.022 & -0.046 & FDI \\
\hline & & & & & & 1.000 & 0.694 & 0.597 & Mobile \\
\hline & & & & & & & 1.000 & 0.636 & Internet \\
\hline & & & & & & & & 1.000 & IHDI \\
\hline
\end{tabular}

$\mathrm{CO}_{2}$ : carbon dioxide. ICT: Information and Communication Technology. CO2mtpc: $\mathrm{CO}_{2}$ emissions (metric tons per capita). CO2inten: $\mathrm{CO} 2$ intensity (kg per kg of oil equivalent energy use). Educ: Quality of primary education. Credit: Private domestic credit. Aid: Foreign aid. FDI: Foreign Direct Investment. Mobile: Mobile phone penetration. Internet: Internet penetration. IHDI: Inequality Adjusted Human Development Index.

\begin{tabular}{|c|c|c|}
\hline Categories & Panels & Countries \\
\hline \multirow{3}{*}{$\begin{array}{l}\text { Income } \\
\text { levels }\end{array}$} & $\begin{array}{l}\text { Middle } \\
\text { Income }\end{array}$ & $\begin{array}{l}\text { Algeria, Angola, Botswana, Cameroon, Cape Verde, Côte d'Ivoire, Egypt, } \\
\text { Equatorial Guinea, Gabon, Lesotho, Libya, Mauritius, Morocco, Namibia, Nigeria, , } \\
\text { Senegal, Seychelles, South Africa, Sudan, Swaziland, Tunisia. }\end{array}$ \\
\hline & Low Income & $\begin{array}{l}\text { Benin, Burkina Faso, Burundi, Central African Republic, Chad, Comoros, Congo } \\
\text { Democratic Republic, Congo Republic, Djibouti, Eritrea, Ethiopia, The Gambia, } \\
\text { Ghana, Guinea, Guinea-Bissau, Kenya, Liberia, Madagascar, Malawi, Mali, } \\
\text { Mauritania, Mozambique, Niger, Rwanda, Sierra Leone, Somalia, Togo, Uganda, } \\
\text { Zambia, Zimbabwe. }\end{array}$ \\
\hline & $\begin{array}{l}\text { English } \\
\text { Common-law }\end{array}$ & $\begin{array}{l}\text { Botswana, The Gambia, Ghana, Kenya, Lesotho, Liberia, Malawi, Mauritius, } \\
\text { Namibia, Nigeria, Seychelles, Sierra Leone, Somalia, South Africa, Sudan, } \\
\text { Swaziland, Uganda, Zambia, Zimbabwe. }\end{array}$ \\
\hline $\begin{array}{l}\text { Legal } \\
\text { Origins }\end{array}$ & $\begin{array}{l}\text { French Civil- } \\
\text { law }\end{array}$ & $\begin{array}{l}\text { Algeria, Angola, Benin, Burkina Faso, Burundi, Cameroon, Cape Verde, Central } \\
\text { African Republic, Chad, Comoros, Congo Democratic Republic, Congo Republic, } \\
\text { Côte d'Ivoire, Djibouti, Egypt, Equatorial Guinea, Eritrea, Ethiopia, Gabon, Guinea, } \\
\text { Guinea-Bissau, Libya, Madagascar, Mali, Mauritania, Morocco, Mozambique, } \\
\text { Niger, Rwanda, Senegal, Togo, Tunisia. }\end{array}$ \\
\hline Religion & Christianity & $\begin{array}{l}\text { Angola, Benin, Botswana, Burundi, Cameroon, Cape Verde, Central African } \\
\text { Republic, Congo Democratic Republic, Congo Republic, Côte d'Ivoire, Equatorial } \\
\text { Guinea, Eritrea, Ethiopia, Gabon, Ghana, Kenya, Lesotho, Liberia, Madagascar, } \\
\text { Malawi, Mauritius, Mozambique, Namibia, Rwanda, Seychelles, South Africa, } \\
\text { South Africa, Togo, Uganda, Zambia, Zimbabwe. }\end{array}$ \\
\hline
\end{tabular}

Islam Algeria, Burkina Faso, Chad, Comoros, Djibouti, Egypt, The Gambia, Guinea, Guinea Bissau, Libya, Mali, Mauritania, Morocco, Niger, Nigeria, Senegal, Sierra Leone, Somalia, Sudan, Tunisia,

Petroleum Algeria, Angola, Cameroon, Chad, Congo Republic, Equatorial Guinea, Gabon, Exporting Libya, Nigeria, Sudan.

Resources

Non-

Petroleum

Benin, Botswana, Burkina Faso, Burundi, Cape Verde, Central African Republic,

Exporting Comoros, Congo Democratic Republic, Côte d'Ivoire, Djibouti, Eritrea, Ethiopia, Egypt, The Gambia, Ghana, Guinea, Guinea-Bissau, Kenya, Lesotho, Liberia, Madagascar, Malawi, Mali, Mauritania, Mauritius, Morocco, Mozambique, Namibia, Niger, Senegal, Sierra Leone, Somalia, Rwanda, Seychelles, South Africa, Swaziland, Togo, Tunisia, Uganda, Zambia, Zimbabwe. 


\begin{tabular}{|c|c|c|}
\hline \multirow{3}{*}{ Stability } & Conflict & $\begin{array}{l}\text { Angola, Burundi, Chad, Central African Republic, Congo Democratic Republic, } \\
\text { Côte d'Ivoire, Liberia, Nigeria, Sierra Leone, Somalia, Sudan, Zimbabwe. }\end{array}$ \\
\hline & Non-Conflict & $\begin{array}{l}\text { Algeria, Benin, Botswana, Burkina Faso, Cameroon, Cape Verde, Comoros, } \\
\text { Congo Republic, Djibouti, Egypt, Equatorial Guinea, Eritrea, Ethiopia, Gabon, The } \\
\text { Gambia, Ghana, Guinea, Guinea-Bissau, Kenya, Lesotho, Libya, Madagascar, } \\
\text { Malawi, Mali, Mauritania, Mauritius, Morocco, Mozambique, Namibia, Niger, } \\
\text { Senegal, Rwanda, Seychelles, South Africa, Swaziland, Togo, Tunisia, Uganda, } \\
\text { Zambia. }\end{array}$ \\
\hline & Landlocked & $\begin{array}{l}\text { Botswana, Burkina Faso, Burundi, Chad, Central African Republic, Ethiopia, } \\
\text { Lesotho, Malawi, Mali, Niger, Rwanda, Swaziland, Uganda, Zambia, Zimbabwe }\end{array}$ \\
\hline $\begin{array}{l}\text { Openness to } \\
\text { Sea }\end{array}$ & $\begin{array}{l}\text { Not } \\
\text { landlocked }\end{array}$ & $\begin{array}{l}\text { Algeria, Angola, Benin, Cameroon, Cape Verde, Comoros, Congo Democratic } \\
\text { Republic, Congo Republic, Côte d'Ivoire, Djibouti, Egypt, Equatorial Guinea, } \\
\text { Eritrea, Gabon, The Gambia, Ghana, Guinea, Guinea-Bissau, Kenya, Liberia, } \\
\text { Libya, Madagascar, Mauritania, Mauritius, Morocco, Mozambique, Namibia, } \\
\text { Nigeria, Senegal, Sierra Leone, Somalia, Sudan, Seychelles, South Africa, Togo, } \\
\text { Tunisia. }\end{array}$ \\
\hline
\end{tabular}

Num: Number of cross sections (countries)

\section{References}

Abor, J. Y., Amidu, Y., \& Issahaku, H., (2018). Mobile Telephony, Financial Inclusion and Inclusive Growth, Journal of African Business, 18(4), 430-453.

Afutu-Kotey, R. L., Gough, K. W., \& Owusu, G., (2017). "Young Entrepreneurs in the Mobile Telephony Sector in Ghana: From Necessities to Aspirations", Journal of African Business, 18(4), pp. 476-491.

Agbor, J. A. (2015). "How does colonial origin matter for economic performance in subSaharan Africa?", In Augustin K. Fosu (Ed.), Growth and Institutions in African Development, Chapter 13, pp. 309-327, Routledge Studies in Development Economics: New York.

Ajide, K. B., Raheem, I. D., \& Asongu, S. A., (2018). "Dollarization and the "Unbundling" of Globalization in sub-Saharan Africa", Research in International Business and Finance. DOI: 10.1016/j.ribaf.2018.09.002.

Akbostanci, E., S. Turut-Asi \& Tunc, G. I., (2009). "The Relationship between Income and Environment in Turkey: Is there an Environmental Kuznets Curve?", Energy Policy, 37(3), pp. 861-867.

Akinlo, A. E., (2008). "Energy consumption and economic growth: evidence from 11 SubSahara African countries". Energy Economics, 30(5), pp. 2391-2400.

Akinyemi, O., Alege, P., Osabuohien, E., \& Ogundipe, A., (2015). "Energy Security and the Green Growth Agenda in Africa: Exploring Trade-offs and Synergies", Department of Economics and Development Studies, Covenant University, Nigeria.

Akpan, G. E. \& Akpan, U. F. (2012). "Electricity Consumption, Carbon Emissions and Economic Growth in Nigeria", International Journal of Energy Economics and Policy, 2(4), pp. 292-306. 
Amavilah, V. H. (2016). "Social Obstacles to Technology, Technological Change, and the Economic Growth of African Countries: Some Anecdotal Evidence from Economic History", Turkish Economic Review, 3(2), pp. 320-340.

Amavilah, V., Asongu, S. A., \& Andrés, A. R., (2017). "Effects of Globalization on Peace and Stability: Implications for Governance and the Knowledge Economy of African Countries", Technological Forecasting and Social Change, 122(September), pp. 91-103.

America, R., (2013). "Economic Development with Limited Supplies of Management. What to do about it - the case of Africa", Challenge, 56(1), pp. 61-71.

Anand, R., Mishra, S., \& Spatafora, N., (2012). "Structural Transformation and the Sophistication of Production," IMF Working Paper No. 12/59, Washington.

Ang, J. B. (2007). "CO2 emissions, energy consumption, and output in France", Energy Policy, 35(10), pp. 4772-4778.

Anyangwe, E. (2014). "Without energy could Africa's growth run out of steam?" theguardian, http://www.theguardian.com/global-development-professionals-network/2014/nov/24/energyinfrastructure-clean-cookstoves-africa (Accessed: 08/09/2015).

Anyanwu, J., \& Erhijakpor, A., (2014). "Does Oil Wealth Affect Democracy in Africa?"African Development Review, 26 (1), pp. 15-37.

Apergis, N. \& J. Payne, J. E., (2009). "CO2 emissions, energy usage, and output in Central America”, Energy Policy, 37(8), pp. 3282-3286.

Ariss, R. T., (2010), "On the Implications of Market Power in Banking: Evidence from Developing Countries", Journal of Banking and Finance, 34(4), pp. 765-775.

Arvis, J-F., Marteau, J-F., \& Raballand, G. (2007). The cost of being landlocked: logistics costs and supply chain reliability", Word Bank Working Paper Series No. 4258, Washington.

Asiedu, E., (2014). "Does Foreign Aid in Education Promote Economic Growth? Evidence From Sub-Saharan Africa", Journal of African Development, 16(1), pp. 37-59.

Asongu, S. A., (2014). "The Questionable Economics of Development Assistance in Africa: Hot-Fresh Evidence, 1996-2010”, The Review of Black Political Economy, 41(4), pp. 455-480.

Asongu, S. A., (2018). "ICT, openness and CO2 emissions in Africa", Environmental Science and Pollution Research, 25(10), pp. 9351-9359.

Asongu, S. A., Anyanwu, J. C., \& Tchamyou, V. S., (2017). "Technology-driven information sharing and conditional financial development in Africa", Information Technology for Development. DOI: 10.1080/02681102.2017.1311833.

Asongu, S. A., \& Boateng, A., (2018). Introduction to Special Issue: Mobile Technologies and Inclusive Development in Africa, Journal of African Business, 19(3), 297-301. 
Asongu, S. A., Efobi, U., \& Beecroft, I., (2015). "Inclusive Human Development in Pre-Crisis Times of Globalisation-Driven Debts”, African Development Review, 27(4), pp. 428-442.

Asongu, S. A., El Montasser, G., \& Toumi, H., (2016). "Testing the relationships between energy consumption, $\mathrm{CO} 2$ emissions, and economic growth in 24 African countries: a panel ARDL approach", Environmental Science and Pollution Research, 23(7), pp. 6563-6573.

Asongu, S. A., \& Le Roux, S., (2017). "Enhancing ICT for inclusive human development in Sub-Saharan Africa", Technological Forecasting and Social Change, 118(May), pp. 44-54.

Asongu, S. A, \& Nwachukwu, J. C., (2016). "The Mobile Phone in the Diffusion of Knowledge for Institutional Quality in Sub Saharan Africa", World Development, 86(October), pp. 133-147.

Asongu, S. A, \& Nwachukwu, J. C., (2018). "Educational quality thresholds in the diffusion of knowledge with mobile phones for inclusive human development in sub-Saharan Africa", Technological Forecasting and Social Change, 129( April), pp. 164-172.

Asongu, S. A. \& Gupta, R., (2016). "Trust and Quality of Growth", Economics Bulletin, 36(3), pp. 1854-1867.

Beck, T., Demirgüç-Kunt, A., \& Levine, R., (2003), "Law and finance: why does legal origin matter?”, Journal of Comparative Economics, 31(4), pp. 653-675.

Beegle, K., Christiaensen, L., Dabalen, A., \& Gaddis, I., (2016). "Poverty in a Rising Africa", Africa Poverty Report, the World Bank, Washington.

http://www.worldbank.org/en/region/afr/publication/poverty-rising-africa-poverty-report

(Accessed: 23/07/2016).

Begum, R. A., Sohag, K., Abdullah S. M. S., \& Jaafar, M., (2015). “CO2 emissions, energy consumption, economic and population growth in Malaysia", Renewal and Sustainable Energy Reviews, 41(January), pp. 594-601.

Boateng, A., Asongu, S. A., Akamavi, R., \& Tchamyou, V. S., (2018). "Information Asymmetry and Market Power in the African Banking Industry", Journal of Multinational Financial Management, 44(March), pp. 69-83.

Bölük, G., \& Mehmet, M., (2015). "The renewable energy, growth and environmental Kuznets curve in Turkey: An ARDL approach", Renewal and Sustainable Energy Reviews, 52(December), pp. 587-595.

Bongomin, G. O. C., Ntayi, J. M., Munene J. C., \& Malinga, C. A., (2018). Mobile Money and Financial Inclusion in Sub-Saharan Africa: the Moderating Role of Social Networks, Journal of African Business, 18(4), 361-384.

Brambor, T., Clark, W. M., and Golder, M., (2006). "Understanding Interaction Models:Improving Empirical Analyses”, Political Analysis, 14 (1), pp. 63-82. 
Byrne, E., Nicholson, B., \& Salem, F., (2011). "Information communication technologies and the millennium development goals", Information Technology for Development, 17(1), pp. 1-3.

Carson, R. T., \& Sun, Y., (2007), "The Tobit model with a non-zero threshold", Econometrics Journal, 10(3), pp. 488-502.

CIA (2011). Central Intelligence Agency, The World Factbook 2011.

Carmody, P., (2013). "A knowledge economy or an information society in Africa?

Thintegration and the mobile phone revolution", Information Technology for Development, 19(1), pp. 24-39.

Chavula, H. K., (2013). "Telecommunications development and economic growth in Africa", Information Technology for Development, 19(1), pp. 5-23.

Coccorese, P., \& Pellecchia, A., (2010), “Testing the 'Quiet Life' Hypothesis in the Italian Banking Industry”, Economic Notes by Banca dei Paschi di Siena SpA, 39(3), pp. 173-202.

Costantini, M., \& Lupi, C., (2005). "Stochastic Convergence among European Economies". Economics Bulletin, 3(38), pp.1-17.

Debusscher, P., \& Ansoms, A., (2013). "Gender Equality Policies in Rwanda: Public Relations or Real Transformations?”, Development and Change, 44(5), pp. 1111-1134.

Diao, X. D., Zeng, S. X., Tam, C. M. \& Tam, V. W .Y., (2009). "EKC Analysis for Studying Economic Growth and Environmental Quality: A Case Study in China", Journal of Cleaner Production, 17(5), pp. 541-548.

Dunlap-Hinkler, D., Kotabe, M., \& Mudambi, R., (2010).“A story of breakthorough versus incremental innovation: Corporate entrepreneurship in the global pharmaceutical industry", Strategic Entrepreneurship Journal, 4(2),pp. 106-127.

Efobi, U., (2015). "Politicians' Attributes and Institutional Quality in Africa: A Focus on Corruption", Journal of Economic Issues, 49(3), pp. 787-813.

Efobi, U., Tanakem, B., \& Asongu, S., (2018). "Female Economic Participation with Information and Communication Technology (ICT) Advancement: Evidence from Sub-Saharan Africa", South African Journal of Economics, 86(2), pp. 231-246.

Esselaar, B., Gilwald, A., \& Stork, C., (2007). "Towards an Africa e-index: Telecommunications sector performance in 16 African countries". Research ICT Africa, www.researchICTafrica.net

Esso, L.J. (2010). "Threshold cointegration and causality relationship between energy use and growth in seven African countries”, Energy Economics, 32(6), pp. 1383-1391.

Fosu, A. K. (2015). "Growth, Inequality and Poverty in Sub-Saharan Africa: Recent Progress in a Global Context”, Oxford Development Studies, 43(1), pp. 44-59. 
Fosu, A., (2013a), "Growth of African Economies: Productivity, Policy Syndromes and the Importance of Institutions" Journal of African Economies, 22(4), pp. 523-551.

Fosu, A. (2013b). Achieving development success: Strategies and lessons from the developing world, UNU-WIDER Policy Brief (November), Helsinki.

Gille, L., Noumba Um, P, Rudel, C., \& Simon, L., (eds) (2002) “A model for calculating interconnection costs in telecommunications". The World Bank. http://www.ppiaf.org/sites/ppiaf.org/files/publication/WB\%20$\% 20$ Model\%20Calculating\%20Interconnection\%20Costs\%20Telecoms\%202004.pdf (Accessed: 27/11/2014).

Gilwald, A., \& Stork, C., (2008). "Towards evidence-based ICT policy and regulation: ICT access and usage in Africa", Volume 1 policy Paper Two, Research ICT Africa, www.researchICTafrica.net .

Gosavi, A., (2018). Can mobile money help firms mitigate the problem of access to finance in Eastern sub-Saharan Africa, Journal of African Business. 18(4), 343-360.

Gutierrez, L. H., Lee, S., \& Virto, L. R., (2009). "Market concentration and performance in mobile markets in Africa and Latin America". OECD Development Center (mimeo).

He, J., \& Richard, P., (2010). "Environmental Kuznets Curve for Co2 in Canada", Ecological Economics, 69(5), pp. 1083-1093.

Hertwich, E. G., \& Peters, G. P., (2009). "Carbon Footprint of Nations: A Global, TradeLinked Analysis", Environmental Science \& Technology, 42, pp 6414-6420.

Hubani, M., \& Wiese, M., (2018). A Cashless Society for All: Determining Consumers' Readiness to Adopt Mobile Payment Services, Journal of African Business, 18(4), 409-429.

Huxster, J. K., Uribe-Zarain, X. \& Kempton, W., (2015). "Undergraduate Understanding of Climate Change: The Influences of College Major and Environmental Group Membership on Survey Knowledge Scores", The Journal of Environmental Education, 46(3), pp. 149-165.

Issahaku, H., Abu, B. M., \& Nkegbe, P. K., (2018). Does the Use of Mobile Phones by Smallholder Maize Farmers Affect Productivity in Ghana?, Journal of African Business, 19(3), 302-322.

Jumbe, C. B., (2004). "Cointegration and Causality between Electricity Consumption and GDP: Empirical Evidence from Malawi”, Energy Economics, 26(1), pp. 61-68.

Kifle, T. (2008). "Africa hit hardest by Global Warming despite its low Greenhouse Gas Emissions", Institute for World Economics and International Management Working Paper No. 108, http://www.iwim.uni-bremen.de/publikationen/pdf/b108.pdf (Accessed: 08/09/2015).

Kamel, S., (2005). "The use of information technology to transform the banking sector in developing nations", Information Technology for Development, 11(4), pp. 305-312. 
Kivuneki, F. N., Ekenberg, L., Danielson, M., \& Tusubira. F.F., (2011). "Perceptions of the role of ICT on quality of life in rural communities in Uganda", Information Technology for Development, 21(1), pp. 61-80.

Koetter, M., Kolari, J. W., \& Spierduk, L., (2008), "Efficient Competition ? Testing the 'Quiet Life' of U.S Banks with Adjusted Lerner Indices", Proceedings of the $44^{\text {th }}$ 'Bank Structure and Competition' Conference, Federal Reserve Bank of Chicago.

Kumbhakar, S. C., \& Lovell, C. A. K., (2000), Stochastic Frontier Analysis, Cambridge MA: Cambridge University Press.

La Porta, R., Lopez-de-Silanes, F., Shleifer, A., \& Vishny, R. W. (1998). "Law and finance", Journal of Political Economy, 106(6), 1113-1155.

La Porta, R., Lopez-de-Silanes, F., Shleifer, A., \& Vishny, R. W. (1999). "The quality of government", Journal of Law, Economics and Organization, 15(1), pp. 222-279.

La Porta, R., Lopez-de-Silanes, F., \& Shleifer, A., (2008), “The Economic Consequences of Legal Origin,” Journal of Economic Literature, 46(2), pp. 285-332.

Levendis, J., \& Lee, S. H., (2013). "On the endogeneity of telecommunications and economic growth: evidence from Asia”, Information Technology for Development, 19(1), pp. 62-85.

McDonald, J., (2009), "Using Least Squares and Tobit in Second Stage DEA Efficiency Analyses", European Journal of Operational Research, 197(2), pp. 792-798.

Mehrara, M., (2007). "Energy consumption and economic growth: The case of oil exporting countries", Energy Policy, 35(5), pp. 2939-2945.

Menyah, K., \& Wolde-Rufael, Y., (2010). "Energy consumption, pollutant emissions and economic growth in South Africa", Energy Economics, 32(6), pp. 1374-1382.

Minkoua Nzie, J. R., Bidogeza, J. C., \& Ngum, N. A., (2018). Mobile phone use, transaction costs, and price: Evidence from rural vegetable farmers in Cameroon, Journal of African Business, 19(3), 323-342.

Mishra, S., Gable, S. L., \&Anand, R., (2011), "Service Export Sophsitication and Economic Growth," World Bank Policy Working Paper No. 5606, Washington.

Mlachila, M., Tapsoba, R., \&Tapsoba, S. J. A., (2017). “A Quality of Growth Index for Developing Countries: A Proposal”, Social Indicators Research, 134(2), pp. 675-710.

Murphy, J. T. \& Carmody, P. (2015). Africa's Information Revolution: Technical Regimes and Production Networks in South Africa and Tanzania, RGS-IBG Book Series, Chichester, UK: Wiley.

Muthinja, M. M., \& Chipeta, C., (2018). What Drives Financial Innovations in Kenya's Commercial Banks? An Empirical Study on Firm and Macro-Level Drivers of Branchless Banking, Journal of African Business, 18(4), 385-408. 
Narayan, P.K., Mishra, S., \& Narayan, S., (2011). "Do market capitalization and stocks traded converge? New global evidence". Journal of Banking and Finance, 35(10), pp. 2771-2781.

Odhiambo, N. M., (2009a). "Electricity consumption and economic growth in South Africa: a trivariate causality test". Energy Economics, 31(5), pp. 635-640

Odhiambo, N. M., (2009b). "Energy consumption and economic growth nexus in Tanzania: an ARDL bounds testing approach". Energy Policy, 37 (2), pp. 617-622.

Olusegun, O. A., (2008). "Consumption and Economic Growth in Nigeria: A bounds testing cointegration approach”, Journal of Economic Theory, 2(4), pp. 118-123.

Ozturk, I., \& Acaravci, A., (2010). "CO2 emissions, energy consumption and economic growth in Turkey", Renewable and Sustainable Energy Reviews, 14(9), pp. 3220-3225.

Penard, T., Poussing, N., Yebe, G. Z., \& Ella, P. N., (2012). "Comparing the Determinants of Internet and Cell Phone Use in Africa: Evidence from Gabon ", Communications \& Strategies, 86(2), pp. 65-83.

Peters, G. P., \& Hertwich, E. G., (2008). "CO2 Embodied in International Trade with Implications for Global Climate Policy", Environmental Science \& Technology, 42(5), pp 1401-1407.

Petrakis, P. E., \&Stamatakis, D. (2002). "Growth and educational levels: a comparative analysis". Economics of Education Review, 21(2), pp. 513-521.

Ponelis, S. R., \& Holmner, M. A., ( 2013a). "ICT in Africa: Enabling a Better Life for All”, Information Technology for Development, 21(1), pp. 1-11.

Ponelis, S. R., \& Holmner, M. A., ( 2013b). "ICT in Africa: Enabling a Better Life for All”, Information Technology for Development, 21(1), pp. 163-177.

Qureshi, S., (2013a). "What is the role of mobile phones in bringing about growth?", Information Technology for Development, 19(1), pp. 1-4.

Qureshi, S., (2013b). "Networks of change, shifting power from institutions to people: how are innovations in the use of information and communication technology transforming development?" Information Technology for Development, 19(2), pp. 97-99.

Qureshi, S., (2013c). "Information and Communication Technologies in the Midst of Global Change: How do we Know When Development Takes Place?", Information Technology for Development, 19(3), pp. 189-192.

Roudometof, V., (2014). "Religion and globalisation", in The SAGE Handbook of Globalisation, Edited by Steger, M., Battersby, P., \& Siracusa, J., Chapter 10, pp. 151-165, SAGE Publications: London.

Seneviratne, D., \& Sun, Y., (2013), "Infrastructure and Income Distribution in ASEAN-5: What are the Links?" IMF Working Paper No. 13/41, Washington. 
Sharp, A., Hoj, S., \& Wheeler, M., (2010). "Proscription and its impact on anti-consumption behaviour and attitudes: the case of plastic bags", Journal of Consumer Behaviour, 9(6), pp. 470-484.

Shurig, S., (2015). "Who will fund the renewable solution to the energy crisis?", theguardian, http://www.theguardian.com/global-development-professionalsnetwork/2014/jun/05/renewable-energy-electricty-africa-policy (Accessed: 08/09/2015).

Ssozi, J., \& Asongu, S. A., (2016). "The Comparative Economics of Catch-Up in Output Per Worker, Total Factor Productivity and Technological Gain in Sub-Saharan Africa", African Development Review, 28(2), pp. 215-228

Tchamyou, V. S., (2017). "The role of knowledge economy in African business", Journal of the Knowledge Economy, 8(4), pp. 1189-1228.

Tchamyou, V. S., (2018a). "Education, Lifelong learning, Inequality and Financial access: Evidence from African countries". Contemporary Social Science. DOI: 10.1080/21582041.2018.1433314.

Tchamyou, V. S., (2018b)."The Role of Information Sharing in Modulating the Effect of Financial Access on Inequality". Journal of African Business: Forthcoming.

Tchamyou, V. S., \& Asongu, S. A., (2017). "Information Sharing and Financial Sector Development in Africa”, Journal of African Business, 18(1), pp. 24-49.

Tchamyou, V.S., Erreygers, G., \& Cassimon, D., (2018). "Inequality, ICT and Financial Access in Africa", Faculty of Applied Economics, University of Antwerp, Antwerp. Unpublished PhD Thesis Chapter.

World Bank (2015). "World Development Indicators", World Bank Publicationshttp://www.gopa.de/fr/news/world-bank-release-world-development-indicators2015 (Accessed: 25/04/2015). 